\title{
The Epidemiological Framework for Biological Invasions (EFBI): an interdisciplinary foundation for the assessment of biosecurity threats
}

\author{
Philip E. Hulme', Richard Baker², Robert Freckleton ${ }^{3}$, Rosemary S. Hails ${ }^{4}$, \\ Matt Hartley ${ }^{5}$, John Harwood ${ }^{6}$, Glenn Marion ${ }^{7}$, Graham C. Smith ${ }^{8}$, \\ Mark Williamson ${ }^{9}$
}

I Bio-Protection Research Centre, Lincoln University, Lincoln, Christchurch PO Box 85084, New Zealand 240 Marygate, York YO30 7BH, UK 3 Department of Animal \& Plant Sciences, University of Sheffeld, Sheffeeld S10 2TN, UK 4 The National Trust, Kemble Drive, Swindon SN2 2NA, UK 5 Zoo and Wildlife Solutions Ltd., Church View, Gresford Road, Hope, Flintshire, LL12 9PW, UK 6 Centre for Research into Ecological \& Environmental Modelling, University of St Andrews, St Andrews, Fife KY16 9LZ, UK 7 Biomathematics \& Statistics Scotland, James Clerk Maxwell Building, The King's Buildings, Edinburgh EH9 3FD, UK 8 National Wildlife Management Centre, APHA, Sand Hutton, York, YO41 1LZ, UK 9 Department of Biology, University of York, York YO10 5DD, UK

Corresponding author: Philip E. Hulme (philip.hulme@lincoln.ac.nz)

Academic editor: J. R. Wilson | Received 25 March 2020 | Accepted 25 May 2020 | Published 15 October 2020

Citation: Hulme PE, Baker R, Freckleton R, Hails RS, Hartley M, Harwood J, Marion G, Smith GC, Williamson M (2020) The Epidemiological Framework for Biological Invasions (EFBI): an interdisciplinary foundation for the assessment of biosecurity threats. In: Wilson JR, Bacher S, Daehler CC, Groom QJ, Kumschick S, Lockwood JL, Robinson TB, Zengeya TA, Richardson DM (Eds) Frameworks used in Invasion Science. NeoBiota 62: 161-192. https:// doi.org/10.3897/neobiota.62.52463

\begin{abstract}
Emerging microparasite (e.g. viruses, bacteria, protozoa and fungi) epidemics and the introduction of non-native pests and weeds are major biosecurity threats worldwide. The likelihood of these threats is often estimated from probabilities of their entry, establishment, spread and ease of prevention. If ecosystems are considered equivalent to hosts, then compartment disease models should provide a useful framework for understanding the processes that underpin non-native species invasions. To enable greater cross-fertilisation between these two disciplines, the Epidemiological Framework for Biological Invasions (EFBI) is developed that classifies ecosystems in relation to their invasion status: Susceptible, Exposed, Infectious and Resistant. These states are linked by transitions relating to transmission, latency and recovery. This viewpoint differs markedly from the species-centric approaches often applied to non-native species. It allows generalisations from epidemiology, such as the force of infection, the basic reproductive ratio $\mathrm{R}_{0}$, super-spreaders, herd immunity, cordon sanitaire and ring vaccination, to be discussed in the
\end{abstract}

Copyright Philip E. Hulme et al. This is an open access article distributed under the terms of the Creative Commons Attribution License (CC BY 4.0), which permits unrestricted use, distribution, and reproduction in any medium, provided the original author and source are credited. 
novel context of non-native species and helps identify important gaps in the study of biological invasions. The EFBI approach highlights several limitations inherent in current approaches to the study of biological invasions including: (i) the variance in non-native abundance across ecosystems is rarely reported; (ii) field data rarely (if ever) distinguish source from sink ecosystems; (iii) estimates of the susceptibility of ecosystems to invasion seldom account for differences in exposure to non-native species; and (iv) assessments of ecosystem susceptibility often confuse the processes that underpin patterns of spread within -and between- ecosystems. Using the invasion of lakes as a model, the EFBI approach is shown to present a new biosecurity perspective that takes account of ecosystem status and complements demographic models to deliver clearer insights into the dynamics of biological invasions at the landscape scale. It will help to identify whether management of the susceptibility of ecosystems, of the number of vectors, or of the diversity of pathways (for movement between ecosystems) is the best way of limiting or reversing the population growth of a non-native species. The framework can be adapted to incorporate increasing levels of complexity and realism and to provide insights into how to monitor, map and manage biological invasions more effectively.

\section{Keywords}

Alien, climate change, COVID-19, eradication, exotic, metapopulation, SEIR; state-and-transition models, vectors

\section{Introduction}

Emerging microparasitic diseases and biological invasions by non-native species represent two of the most significant biological threats to the survival of endangered species, the ecological integrity of ecosystems, the economic productivity of agriculture and the quality of human health (Early et al. 2016; Halliday et al. 2017; Ogden et al. 2019; Paini et al. 2016). There are fundamental differences between microparasites (e.g. viruses, bacteria, protozoa and fungi) and non-native species (e.g. plants, invertebrates and vertebrates) in their life-history and epidemiology (Table 1, Morand et al. 2015). However, invasions by microparasites and non-native species can be similarly conceptualised as comprising a minimum of two interacting components: an agent (e.g. microparasite or non-native species) and one or more receptors (e.g. host or ecosystem). They also share commonalities in that they both require an agent to be introduced into a new area, for it then to establish and reproduce and subsequently spread over large spatial scales (either naturally or via a vector) when it may have an impact on the environment, as well as human, plant or animal health. The similarity in the process of invasion is such that the threats these different classes of invader pose to the environment, human, plant or animal health are often assessed using the same risk assessment tools (Baker et al. 2008; Ireland et al. 2020). Indeed, when non-native species act as hosts, their spatial dynamics often play an important role in the introduction, establishment and spread of microparasites (Bufford et al. 2016; Hulme 2014).

Epidemiologists have highlighted the crucial importance in disease management of integrating the population dynamics of the agents, as well as the states and transitions amongst receptors (Diekmann et al. 2013; Loker and Hofkin 2015; Wilson et al. 
Table I. Differences between microparasites and non-native species that are considered in the Epidemiological Framework for Biological Invasions.

\begin{tabular}{|c|c|c|}
\hline Characteristic & $\begin{array}{l}\text { Microparasites (e.g. virus, bacteria, fungus) } \\
\text { infecting animal or plant hosts }\end{array}$ & $\begin{array}{c}\text { Non-native species (e.g. plant, invertebrate, } \\
\text { vertebrate) invading ecosystems }\end{array}$ \\
\hline $\begin{array}{l}\text { Agent } \\
\text { demography }\end{array}$ & $\begin{array}{l}\text { Demography of the agent within a host is rarely } \\
\text { quantified and is assumed to play a limited role } \\
\text { in disease epidemiology }\end{array}$ & $\begin{array}{l}\text { Non-native species population dynamics within } \\
\text { ecosystems are important in invasion dynamics }\end{array}$ \\
\hline $\begin{array}{l}\text { Agent } \\
\text { distribution }\end{array}$ & $\begin{array}{l}\text { Distribution of parasites amongst hosts is } \\
\text { rarely modelled apart from whether infected or } \\
\text { uninfected }\end{array}$ & $\begin{array}{l}\text { Density varies amongst individual ecosystems } \\
\text { and will influence demography and dispersal }\end{array}$ \\
\hline $\begin{array}{l}\text { Agent } \\
\text { specificity }\end{array}$ & Usually one or a few closely-related hosts & $\begin{array}{l}\text { Can often be generalists found in many different } \\
\text { ecosystem types }\end{array}$ \\
\hline $\begin{array}{l}\text { Host } \\
\text { distinctiveness }\end{array}$ & $\begin{array}{l}\text { Usually easily defined (e.g. a particular species } \\
\text { such as Homo sapiens) for which individuals can } \\
\text { be distinguished }\end{array}$ & $\begin{array}{l}\text { Ecosystems are more problematic to define as } \\
\text { hosts, since they can sometimes grade into each } \\
\text { other }\end{array}$ \\
\hline $\begin{array}{l}\text { Host } \\
\text { heterogeneity }\end{array}$ & $\begin{array}{l}\text { Low heterogeneity amongst susceptible hosts } \\
\text { arising from similarities in physiology and } \\
\text { immunology within a species }\end{array}$ & $\begin{array}{l}\text { High heterogeneity amongst susceptible } \\
\text { hosts due to differences in abiotic conditions } \\
\text { and biotic communities within each class of } \\
\text { ecosystem }\end{array}$ \\
\hline $\begin{array}{l}\text { Host } \\
\text { immunity }\end{array}$ & $\begin{array}{l}\text { Hosts, especially vertebrates, may naturally } \\
\text { acquire short- or long-term immunity following } \\
\text { infection }\end{array}$ & $\begin{array}{l}\text { Ecosystems do not normally acquire natural } \\
\text { immunity to further invasion by a species } \\
\text { following its initial colonisation }\end{array}$ \\
\hline Host mobility & $\begin{array}{l}\text { Animal hosts are often mobile and host } \\
\text { movements can be critical in the dynamics of } \\
\text { disease }\end{array}$ & $\begin{array}{l}\text { Ecosystems are, to all intents and purposes, } \\
\text { immobile and thus, as hosts, may be better } \\
\text { captured by plant epidemiological models }\end{array}$ \\
\hline Host scale & $\begin{array}{l}\text { With the exception of age-related variation, the } \\
\text { size of a particular host species is similar across } \\
\text { individuals }\end{array}$ & $\begin{array}{l}\text { For a single ecosystem type, the area of individual } \\
\text { localities can vary considerably }\end{array}$ \\
\hline Host vital rates & $\begin{array}{l}\text { Hosts can die as a result of infection and can be } \\
\text { born }\end{array}$ & $\begin{array}{l}\text { Ecosystem are not usually viewed as having vital } \\
\text { rates }\end{array}$ \\
\hline Vectors & $\begin{array}{l}\text { Usually a living organism (e.g. mosquito, } \\
\text { aphid) that carries microparasites from one host } \\
\text { individual to another }\end{array}$ & $\begin{array}{l}\text { Often a physical vehicle (e.g. train, car, boat) that } \\
\text { transports a non-native species but can include } \\
\text { living organisms (e.g. birds, humans) }\end{array}$ \\
\hline
\end{tabular}

2019). Invasions by microparasites and non-native species are inherently spatial processes, frequently affected by the distribution of receptors and the extent to which the (meta)populations of receptors are subdivided into networks of smaller, partly isolated, subunits (Briscoe et al. 2019; Seabloom et al. 2015; Tadiri et al. 2018). However, with the exception of plants, most hosts of microparasites are mobile and host movements can be critically important in the dynamics of disease. In contrast, ecosystems are, to all intents and purposes, immobile. Thus the spatial structure of ecosystems, particularly the extent of spatial clustering and the connectivity of the landscape, will likely play a more important role in biological invasions. Therefore, in many respects, the dynamics of agents and receptors in the invasion of ecosystems will have greater parallels with the epidemiology of plant than animal diseases.

Progress in understanding the dynamics of biological invasions has largely been agentcentred (Hui and Richardson 2017; Jeschke and Heger 2018; Liebhold et al. 2020). Given the important contribution of receptor-centred approaches in disease epidemiology, extending this perspective to biological invasions may similarly deliver considerable 
insights if ecosystems can be classified in terms of their susceptibility and exposure to non-native species, their contribution to the spread of invasions (i.e. their infectivity) and the likelihood and duration of any recovery. Furthermore, a more aligned approach to the study of biological invasions that builds on ideas developed within disease epidemiology will facilitate cross-fertilisation between the disciplines and, as a result, may deliver more comprehensive biosecurity policies (Crowl et al. 2008; Ogden et al. 2019).

Current understanding and management of emerging diseases has benefited from the progressive development of a multitude of epidemiological models (Diekmann et al. 2013; Kleczkowski et al. 2019; Rock et al. 2014). Yet despite a rich tradition of theory underpinning biological invasions (Hengeveld 1989; Lewis et al. 2016; Shigesada and Kawasaki 1997), epidemiological perspectives in this field have largely focused on the analysis of introduced microparasites of humans (Li et al. 2019; Sun et al. 2018), animals (Orsel et al. 2009; Samuel et al. 2011) or plants (Cunniffe et al. 2016; Soubeyrand et al. 2018). Underlying all dynamical system models of epidemiological processes is the basic SIR framework (Fig. 1A) in which receptors (e.g. hosts) are categorised into three compartments: Susceptible, Infectious and Resistant (sometimes classed as Removed or Recovered), based on their infection status (Blackwood and Childs 2018; Gilligan 2008; Kleczkowski et al. 2019). Some infections do not provide long-lasting acquired immunity (e.g. HIV), which may parallel ecosystems for which resistance from invasion is either impossible or short-lived and, in these circumstances, an SIS model (Susceptible-Infectious-Susceptible) may be more appropriate (Diekmann et al. 2013). The independent variable in compartment disease models is time $t$ and the rates of transfer between compartments is described by a series of ordinary differential equations that capture transmission and recovery rates (Brauer and Castillo-Chavez 2010). Simple SIR compartment disease models have provided important insights into disease epidemiology and can be readily expanded to capture more complex phenomena through the inclusion of additional compartments. However, these complex models often exhibit types of behaviour that are qualitatively similar to the simplest SIR model (Brauer and Castillo-Chavez 2010). Could such an approach also provide insights into biological invasions by species that are not pathogens or parasites?

Some might argue that, unlike hosts which are discrete entities (individual animals or plants), many ecosystems have far less clear-cut and temporally-stable boundaries (Evans and Brown 2017; Oliveras and Malhi 2016). The difficulty of the ecosystem concept is not exclusive to the field of biological invasions and it is understood to be an ad hoc construct on the part of an observer for a particular purpose (Gignoux et al. 2011). An important difference from the hosts of microparasites is that ecosystems show much greater heterogeneity, both amongst different ecosystem types (e.g. tallgrass prairie, deciduous temperate forest, heathland), but also within a particular ecosystem type as a result of variation in biotic and abiotic conditions. Similarly, within a single ecosystem type, the areas of different localities can vary across many orders of magnitude (e.g. 0.1 to $>10,000 \mathrm{~km}^{2}$ ), as in the case of lake ecosystems (Downing et al. 2006). Nevertheless, there is a long history of compartmentalising ecosystems into representative units. State-and-Transition Model (STM) approaches have long been used to define 
a discrete ecosystem, identify alternative ecosystem states and quantify the abiotic (e.g. drought, fire, eutrophication) and biotic (e.g. grazing, insect outbreaks) drivers that lead to transitions from one ecosystem state to another (Bestelmeyer et al. 2017). The STM framework has increasingly been used to model shifts in ecosystem state as a result of biological invasions by non-native plants, pathogens and animals (Cobb et al. 2017; Jarnevich et al. 2019; Perry et al. 2015; Stein et al. 2016). Furthermore, STMs are also one of the most widespread modelling techniques in clinical decision analysis to capture transitions in disease status of individual patients (Siebert et al. 2012). While STMs are superficially similar in structure to SIR models (Fig. 1B), the rates of transfer between compartments (states) is usually described by linear models that capture the effect of combinations of biotic and abiotic drivers (Bestelmeyer et al. 2017). Thus progressive deterioration of an ecosystem due to human activities can be captured by flows from a pristine ecosystem to one that is disturbed as a result of anthropogenic fire regimes that, if not restored, would further degrade under the pressure of overgrazing (Fig. 1B).

The foregoing discussion of SIR and STM approaches highlights a sufficient number of parallels between microparasitic diseases and non-native species invasions to suggest that the bringing together of these different compartment perspectives may provide a valuable framework to further the current understanding of biological invasions. Indeed, epidemiological compartment models have been applied to describe the status of farms as Susceptible or Infectious in the analysis of foot-and-mouth disease (Rossi et al. 2017) and, thus, it is only a small step to extend this perspective to ecosystems. Compartment models have provided the basis for key epidemiological insights including: thresholds for disease persistence, rate limiting functions for microparasite population growth, criteria for stable dynamics, impact of different transmission functions on disease spread and optimal control strategies (Kleczkowski et al. 2019; Rock et al. 2014). Similarly, STMs have been used to detect thresholds, identify positive and negative feedbacks, as well as indicate the reversibility of change in ecosystem properties (Bestelmeyer et al. 2017). By linking together these different modelling perspectives, the opportunity therefore exists to:

1. Construct an epidemiological framework that captures the fundamental components of a compartment disease model for non-native species and invaded ecosystems.

2. Assess the relevance of the framework to non-native invasion dynamics in relation to the large body of theory that has addressed microparasite infections.

3. Examine the implications of the compartment disease model perspective for the management of biological invasions at the ecosystem level.

Given that epidemiological studies on non-native species have only been undertaken on those species that are pathogenic or parasitic (Lewis et al. 2016), there are currently insufficient data to build an epidemiological model for biological invasions by non-native plants, invertebrates or vertebrates. Nevertheless, by outlining a structure and the necessary parameters, a framework can provide a robust foundation for future modelling approaches. 


\section{A. Schematic SIR model}

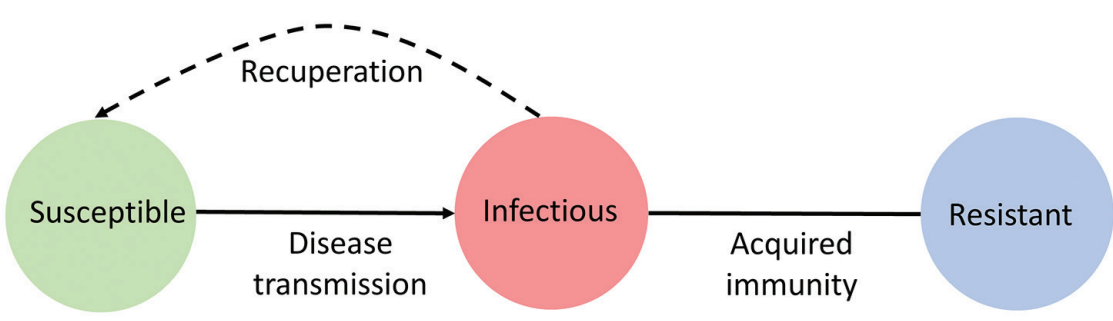

B. Schematic STM model

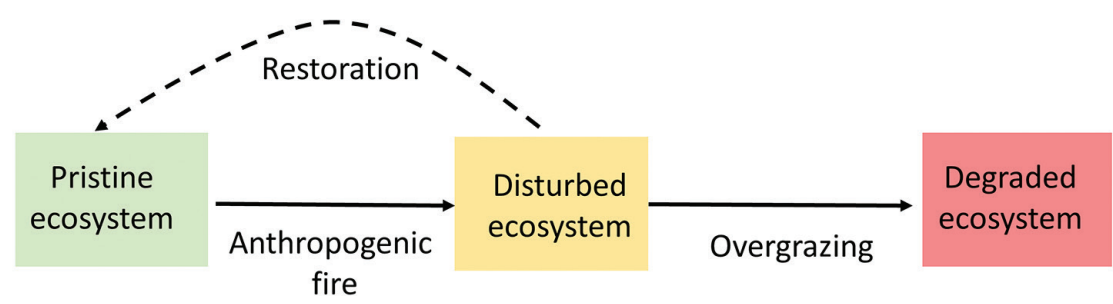

Figure I. Similarities between a simple Susceptible-Infectious-Resistant compartment model for a microparasitic disease and a state-and-transition model describing progressive ecosystem degradation. Both types of model show transitions between different states (solid arrows) with potential for reversal (dotted arrows).

\section{Components of an Epidemiological Framework for Biological Invasions}

The SIR model (Fig. 1A) has been widely adapted to include greater complexity including additional compartments, such as Exposed but not Infectious (capturing latency in infectiousness), cryptic Infectious (infectiousness prior to the onset of symptoms), Immunised (as a result of vaccination) and Quarantine (temporally isolated), as well as subdividing individual compartments by age-class or behaviour (Brauer and CastilloChavez 2010). The proposed framework for non-native species combines elements of both SEIR (Susceptible - Exposed - Infectious - Resistant) and SEIS (Susceptible Exposed - Infectious - Susceptible) models of microparasite infections to characterise the ecosystem states and transitions that are more appropriate for the management of biological invasions (Fig. 2). Within the framework, an ecosystem can also be considered to exist in one of four different states in relation to a non-native species: Susceptible $(S)$; Exposed $(E)$; Infectious $(I)$; and Resistant $(R)$. The key flows linking the four states are the force of infection $(\lambda)$ between Infectious and Susceptible ecosystems, the probability of transition from Exposed to Infectious $(\sigma)$, the rate of natural recovery of Infectious ecosystems ( $\xi$ ), the rate of recovery of Infectious ecosystems following management $(\gamma)$, the rate at which Exposed ecosystems revert to the Susceptible state $(\theta)$, the rate at which Resistant ecosystems enter the Susceptible state $(v)$ and the rate 


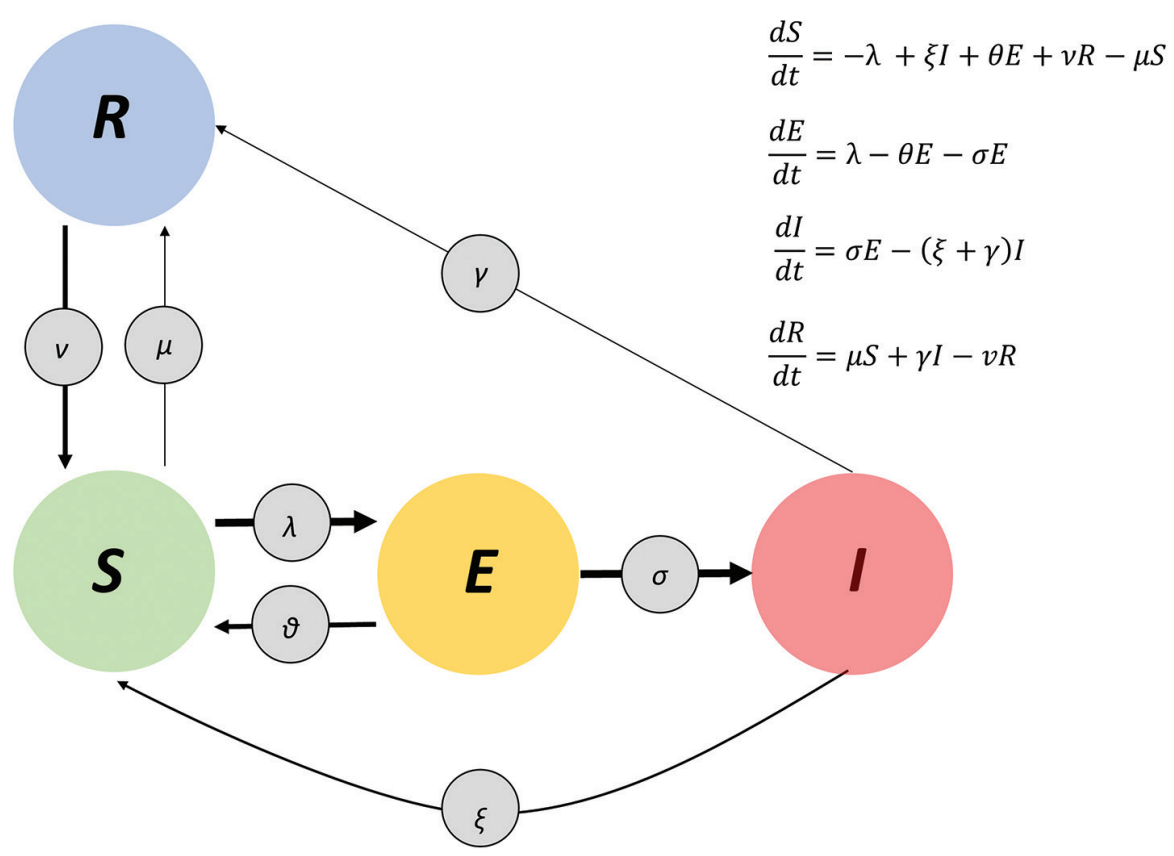

Figure 2. Schematic compartment model illustrating how ecosystems may be classified into four invasion states (Susceptible, Exposed, Infectious and Resistant) linked by transitions relating transmission of nonnative species amongst ecosystems, exposure and recovery. The characteristic dynamics within a receptor will exhibit three phases: a period prior to colonisation; growth as the local population increases; followed by fluctuations around the steady state. These phases can be identified with the epidemiological categorisations of Susceptible (no non-natives present), Exposed (low numbers of non-natives with essentially no dispersal) and Infectious (a viable population of non-native species contributing to dispersal). Termination of the Infectious state corresponds to the collapse of the meta-stable population due to stochastic events or some externally driven change (e.g. in the birth or death rates) or intervention which removes the local population and results in the receptor returning to either being Susceptible again or Resistant. Transitions between the four different states are: $\lambda=$ the force of infection between Infectious and Susceptible ecosystems; $\theta=$ the rate at which an Exposed receptor reverts to become Susceptible; $\sigma=$ the latency between initial exposure and infectivity; $\xi=$ the rate of natural recovery of Infectious ecosystems to the Susceptible state; $\gamma=$ the rate recovery of Infectious ecosystems following management to the Resistant state; $\nu=$ the rate which Resistant ecosystems enter the Susceptible state; $\mu=$ the rate which Susceptible ecosystems become Resistant. The total number of ecosystems $(N)$ is given by the sum of the number of ecosystems in each state. Different weights for each arrow are for illustration only to highlight that transition rates between compartments differ and illustrate the probable importance of different transitions in biological invasions.

at which Susceptible ecosystems become Resistant $(\mu)$. The total number of ecosystems $(N)$ is given by the sum of the number of ecosystems in each state.

The overall framework proposed is simpler than compartment disease models since sex-structure, maternal effects and vertical transmission do not have clear equivalents when applied to ecosystems. Although ecosystems can be created and destroyed by humans (e.g. creation of water reservoirs versus the draining of lakes), the model does 
not include any processes that increase or reduce the numbers of ecosystems. A further difference is that many ecosystems, either inherently or through human activities, may be entirely unsuitable for occupation by a particular non-native species. These ecosystems are described as Resistant since the growth rate of a non-native population is likely to be negative and extinction will be an inevitable consequence of any colonisation event. Resistant ecosystems are only included in compartment models if they can become Susceptible through some external agency (e.g. climate change, anthropogenic disturbance), otherwise they play no part in the epidemiology of invasion. Resistant ecosystems may be transformed into Susceptibles (at a rate $v$ ) by a range of external pressures (e.g. fire, grazing, climate change, eutrophication). Similarly, Susceptibles can be transformed into the Resistant state (at a rate $\mu$ ) by the reversal of many of those pressures. In contrast to SEIR models, this can occur without having to pass through the Exposed state. Thus, unlike standard SEIR models, at the beginning of any simulation, the Resistant state will contain ecosystems that have never been Exposed, but are capable of being transformed to become Susceptible.

The characteristic dynamics of non-native species within an ecosystem will exhibit three phases: a period associated with early colonisation; growth of the non-native population; followed by fluctuations around a steady state. These phases correspond to the following states: Susceptible (no agent present), Exposed (low numbers of agents with no dispersal outside of the ecosystem) and Infectious (a viable population of agents contributing to dispersal). Transition from the Exposed (at a rate $\theta$, Fig. 2) or Infectious (at a rate $\xi$, Fig. 2) states to Susceptible or from Susceptible (at a rate $\mu$, Fig. 2) or Infectious (at a rate $\gamma$, Fig. 2) states to Resistant corresponds to the collapse of the population due to stochastic events or some externally-driven change, such as the eradication of the non-native population from the ecosystem. The following sections use examples drawn from both the epidemiological and invasion literature to illustrate the utility of the Epidemiological Framework for Biological Invasions and highlight similarities in the factors that determine the different states and the flows that link them. These similarities emphasise how epidemiological perspectives can advance current understanding of biological invasions.

\section{Relevance of an Epidemiological Framework for Biological Invasions}

By examining the similarities and differences between microparasitic diseases and nonnative species invasions for the different compartments of an SEIR disease model, it may be possible to identify the key parameters of an Epidemiological Framework for Biological Invasions that will facilitate cross-fertilisation between disease and invasion biology.

\section{Susceptibility}

Certain ecosystems are known to be inherently more susceptible to the colonisation by a non-native species than others. At any one time within a population of $N$ ecosystems (which could be different ecosystem types or different areas of a single ecosystem type), the 
rate of change in the number of Susceptible ecosystems $(S)$ will be a function of the rate at which Susceptibles become infected and move to the Exposed class ( $\lambda$, the force of infection), become resistant and move to the Resistant class $(\mu S)$, as well as the rates at which Infectious ( $\xi)$, Exposed $(\theta E)$ and Resistant $(v R)$ classes become Susceptible (Fig. 2, Eqn 1).

$$
\frac{d S}{d t}=-\lambda+\xi I+\theta E+\nu R-\mu S
$$

Susceptibility can be viewed at two levels: amongst different types of receptors (e.g. woodlands, grasslands and wetlands) and within a single receptor type (e.g. coniferous forest). Intriguingly, the balance of effort has differed between disease and invasion studies: the former have focused more strongly on intra-host variability (Fellous et al. 2012; Tack et al. 2014; Vale 2013), whereas the latter have largely addressed why some ecosystems are more vulnerable to invasion than others. This is understandable since many microparasites have a relatively-narrow host range (Loker and Hofkin 2015), but a single non-native species can often colonise a wide range of different ecosystem types (Affre et al. 2010). Nevertheless, similarities exist in the factors influencing the relative susceptibility of different host species to microparasites and ecosystems to non-native species. For example, the absence of specific tissue or cellular receptors for colonisation of hosts by microparasites (Doran et al. 2016; Toruno et al. 2016) is equivalent to the absence of suitable resources (e.g. diet, habitat, symbiont) for a non-native species (Gioria and Osborne 2014). Temperature of the host may limit microparasite growth (Fang et al. 2016), just as it can limit the establishment of poikilothermic non-native animals and frost-intolerant plants (Hulme 2017). A lack of the exact nutrient requirements to support microparasite growth or development (Johnson et al. 2010; Smith 2007) corresponds with the scarcity of non-native plants in nutrient-poor habitats. Even the dynamic nature of a host's immune response through phagocytic defences may have its counterpart in the role of natural enemies in limiting non-native species to certain ecosystems (Schulz et al. 2019). External drivers of susceptibility, such as ecosystem fragmentation and land-use change, can similarly affect invasions by non-native species (Riitters et al. 2018), as well as the spread of infectious diseases (Gottdenker et al. 2014).

Analogous factors also exist that influence susceptibility to microparasites and nonnative species within a specific host or ecosystem. Host age, homeostatic disturbance, intercurrent disease, microbial antagonism and MHC diversity have all been proposed to influence host susceptibility to microparasites (Casadevall and Pirofski 2018). A similar list can be generated for the susceptibility to non-native species of an individual ecosystem type that includes successional age, habitat disturbance, the presence of other non-native species, competition with resident species and native species diversity (Guo et al. 2015). The concept of "invasional meltdown", where one non-native species facilitates the invasion by other species (Simberloff 2006), has similarities in the multiple opportunistic bacterial infections of individuals with HIV (Joos et al. 2007). Susceptibility is not necessarily an immutable characteristic of a receptor and external drivers, such as climate change, increases or decreases in resource supply, pollution etc., can lead to previously Resistant receptors becoming Susceptible (Guo et al. 2015; Johnson et al. 2010). 
However, an important issue when examining ecosystem vulnerability to invasion is the need to control for variation in exposure to colonisation by non-native species (e.g. propagule pressure), because this is rarely independent of the type of ecosystem. When this has been taken into account, emerging hypotheses are that ecosystems that naturally experience recurrent disturbances and are rich in available nutrients are most susceptible to invasion (Aikio et al. 2012; Chytrý et al. 2008). The receptor-centred framework presented here requires that inherent susceptibility is assessed independently of exposure (e.g. propagule pressure and force of infection), since it provides the basis for clearer prioritisation of the ecosystems most at risk from biological invasions (Catterall et al. 2012).

\section{Force of infection and transmission}

The transitions between the Susceptible and Exposed and Infectious states have received considerable empirical and theoretical attention with reference to the factors shaping disease transmission (Johnson et al. 2019). The force of infection $(\lambda)$ depends on the number of Susceptible receptors $(S)$, the proportion of Infectious receptors $(I / N)$ and the transmission rate $(\beta)$ which is a function of the rate of contact between receptors and a per-contact probability of infection (Kleczkowski et al. 2019).

$$
\lambda=\frac{\beta S t}{N}
$$

Epidemiological approaches have tended to focus on the spread of a disease following its establishment in the host population (Diekmann et al. 2013), whereas the study of biological invasions has stressed the role of propagule pressure (i.e. the number and frequency with which individuals of a particular non-native species are introduced) in determining whether or not the agent will establish itself in a specific ecosystem (Simberloff 2009). However, estimation of propagule pressure has largely focused on the raw numbers of individuals of a particular non-native species arriving into an ecosystem (equivalent to the contact rate) and less on the likelihood of establishment per contact (equivalent to the per-contact probability of infection). Vectors often facilitate the transmission of agents of disease and non-native species. Yet, although the terminology is the same, the processes by which vectors transmit microparasites and spread non-native species are often quite different. In epidemiology, a vector is usually an alternative host, whose demography and status (Susceptible, Exposed, Infectious etc.) is a fundamental component of disease dynamics. Furthermore, living vectors may exhibit specific host-seeking behaviour that will increase transmission rates (Wynne et al. 2020). In contrast, the most important vectors of non-native species are humans and human-driven instruments (e.g. boats, trains, cars) that may provide passive transport between locations (Hulme et al. 2008). The extent to which such passive vectors link similar ecosystems and facilitate transmission has yet to be explored in detail. There 
are, of course, exceptions to this dichotomy, such as the role played by unclean needles in the spread of HIV amongst intravenous drug users (Smith et al. 2005), the deliberate mailing of anthrax spores to unfortunate victims (Arora et al. 2012)), the role of frugivores in the dispersal of non-native plants (Dawson et al. 2011) and the many occasions where humans have selected, bred and deliberately released non-native species for hunting, fishing or biological control. It is becoming increasingly clear that, just as in the case of non-native species, complex vector components and multiple hosts are often involved in the transmission of emerging zoonotic diseases (Engering et al. 2013; Hulme 2014).

In the case of local direct transmission or spread of diseases, the simplest model assumes that exposure is a product of the numbers of Susceptible and Infectious receptors linked by a transmission function (Diekmann et al. 2013; Kleczkowski et al. 2019). Epidemiological SEIR models often assume homogenous mixing of Susceptible and Infectious receptors as a result of random movement of the receptors, but ecosystems cannot be assumed to "mix" in the same way as mobile hosts. The assumption of homogeneous mixing can provide general insights once an epidemic is well established, but can lead to errors if incorrectly assumed at the earliest stages (Del Valle et al. 2013). Instead, invasion models have focused on the agents' dispersal kernel (Sullivan et al. 2017). Models of the dispersal of non-native species have moved from simple diffusion processes to explore stratified dispersal (multiple functions) and integro-difference equation approaches in order to capture the importance of rare long-distance dispersal events (Kot et al. 2012). Such dispersal models may be equally appropriate for microparasites, as in the case of foot and mouth disease in the UK, where local spread was from aerial plumes and typically modelled via a transmission kernel, based on Euclidean distance, but long distance movement occurred via vehicles (Keeling et al. 2003). Indeed, there is an increasing push to model microparasite transmission and non-native species dispersal in similar ways (Lindström et al. 2011).

Where mixing is known to be non-random but the variation in individual contact rates is poorly known, lattice models, in which random connections between neighbouring sites facilitate transmission, have been used to assess the role of connectivity and spatial heterogeneity in disease epidemics (Liccardo and Fierro 2015). However, when the movement of agents is facilitated by human activity (e.g. shipping, airfreight, railroads) and the origins and destinations of the activity are known, gravity models can be used to assess the potential spread of disease (Charu et al. 2017) and non-native species (Drake and Mandrak 2014). These models estimate rates of transmission as a function of the distance between receptors. Where additional data are available on contact rates between receptors, network models are appropriate to predict future disease and non-native threats (Silk et al. 2017). Receptors have transmission contacts only along the links in a specified network of hosts or ecosystems. The existence of a connection predisposes the receptors to infection, but does not guarantee it. The number of connections each receptor has with others can be modelled by choosing a particular degree distribution for the network (e.g. a power-law would describe most receptors having few connections but a small number having many). In these models, the agent 
usually originates in one or more randomly-selected Infectious nodes in a population that is otherwise made up of Susceptible receptors. For discrete time models, in every time-step, all the Susceptible neighbours of the Infectious nodes become infected with probability $\beta$ (the transmission rate) per Infectious neighbour (Enright and Kao 2018).

Network models have been used to model the connections between individuals linked to the spread of sexually-transmitted diseases (Beyrer et al. 2012), the spread of COVID-19 in cities (Xue et al. 2020), the global movement of shipping that enables the spread of non-native species (Seebens et al. 2019), the dissemination of plant pathogens through international horticultural trade (Moslonka-Lefebvre et al. 2011) and parasite transmission in wildlife (White et al. 2017). Different network topologies have a significant impact on disease dynamics and can have a stronger impact on outbreak magnitude than fundamental microparasite features such as transmission rate, infection duration and immunisation ability with important implications for management and control (Strona et al. 2018). In both gravity and network models, key considerations underpinning the likelihood of transmission include the life-history traits of the agent, such as how likely it is to survive and/or increase in prevalence during transport, the ease of detection of the agent or its symptoms, as well as attributes of the pathways (or connections) themselves. These attributes include the duration and condition of transport and the probability of transfer to suitable receptors on arrival. As the importance of landscape and spatial heterogeneity in the transmission and dispersal of disease and non-native species is recognised, so it is likely that these fields will increasingly converge on common modelling approaches (Claflin et al. 2017; de la Fuente et al. 2018; Kirby et al. 2017).

\section{Exposure and latency}

Once it has been infected or colonised by an agent and assuming there is growth of the agent population, a Susceptible receptor enters the Exposed state. The transition of Exposed receptors to the Infectious state is determined by the latent period or lag-phase (determined by $1 / \sigma$ ), that reflects the time elapsed before the emergence of symptoms of disease or noticeable impacts of the non-native species. For many diseases, the "latent period" is so brief that the Exposed state is not incorporated into compartment models, although the human prion disease, kuru, has an incubation period of between 40 and 60 years (Collinge et al. 2006). In contrast, the temporal dynamics of many non-native species show a marked "lag-phase" between initial colonisation and subsequent spread that can span several decades (Aikio et al. 2010; Coutts et al. 2018; Rouget et al. 2016). Drake (2005) compared the latent-period of bovine tuberculosis (Mycobacterium bovis) infection and the lag-phase in the spread of coypu (Myocastor coypus) in the UK and concluded that their different durations may be explained by the demographic stochasticity associated with small founder populations. Thus, the transition from the Exposed state reflects the turnover of agents within the receptor, which is determined by their rates of immigration, establishment, reproduction and mortality. In contrast to most microparasite SEIR models, epidemiological invasion models require knowledge of the 
population dynamics of the agent within the receptor. These mathematical models will need to track the population size of the non-native species within each particular ecosystem that has become Exposed, rather than simply their presence or absence. Allee dynamics, where populations experience low or negative per capita growth rates at low densities can result in longer lag-phases, slower spread and decreased establishment likelihood of both non-native species and microparasites (Tobin et al. 2011). During this phase, the agent may become extinct as a result of demographic stochasticity, in which case the receptor will revert to the Susceptible state (Fig. 2). The latent-period or lag-phase may also result from genetic processes including: selection and adaptation of agent genotypes to the receptor environment, purging of genetic load responsible for inbreeding depression, accumulation of additive genetic variation and recovery from loss of genetic diversity (Pysek and Hulme 2005; Vieira et al. 2019). Under these circumstances, the duration of the Exposed state may reflect the strength of selection pressures, generation time of the agent and the genetic diversity of the inoculum.

\section{Infectivity}

Once exposed and possibly following a latent period or lag-phase, a receptor may become Infectious. Whether or not an Exposed receptor transitions to the Infectious state will depend on the ability of the agent population to produce migrants or propagules that can colonise other receptors. This ability will be affected by the nature of density-dependence (including Allee effects) and the generation time of the agent (Cassey et al. 2014; Drake and Lodge 2006). Transmission of agents from one receptor to another may be passive (e.g. virus shedding, oocytes in faeces, wind-dispersed seeds) or via a vector (e.g. mosquito, frugivore, vehicle). For microparasites, the length of the infectious period, during which migrants or propagules are generated, can range from only a few days (e.g. COVID-19) to a decade or more (e.g. HIV). In contrast, without intervention, many non-native species can persist in ecosystems for centuries (Hulme 2020) and which therefore remain Infectious almost indefinitely. It might be expected that the likelihood of transmission to other receptors will be a function of local (within-receptor) population size, as it is in many macroparasites (Hollingsworth et al. 2015). Nevertheless, population size is only one factor influencing transmission rates since agents need to be dispersed and make contact with Susceptible receptors. Contact rates will reflect the attraction of receptors to agents or their vectors. This attraction and the availability of suitable vectors will influence both the spread of disease and non-native species. This is equally true for the host feeding preference of mosquitoes (Takken and Verhulst 2013) or the suitability of lake ecosystems for recreational anglers (Oh et al. 2018). In addition, the ultimate probability of transmission should increase as the duration of the infectious period lengthens.

While metapopulation models have been used to understand the spatial dynamics of disease (Grenfell and Harwood 1997; Parratt et al. 2016; Wang and Wu 2018) and non-native species (Pichlmueller and Russell 2018; Tamburello et al. 2019), attention has 
primarily focused on the demographic attributes of the agent rather than the infectivity of receptors. Within the Epidemiological Framework for Biological Invasions, Infectious receptors are those within which an agent can reproduce and from which it can disperse, either naturally or with human assistance. Not all receptors are equally likely to play a role in the spread of an agent, a number will act as sources (where agent population growth is positive) and others as sinks (where agent population growth is negative or dispersal is prevented) of varying strengths (Geoghegan et al. 2016). The importance of an Infectious receptor to the spread of an agent will be a function of its connectivity (e.g. existence of invasion corridors, proximity to Susceptible receptors) and of the agent's life-history.

The minimum evidence for classifying a receptor as Infectious is the persistence of the microparasite or non-native species. Such evidence is usually obtained through expression of symptoms or impacts on the receptor or detection of a persistent population of the agent using serological techniques or field surveys. Nevertheless, not all receptors classified as Infectious in this way may actually be capable of infecting Susceptible receptors. Furthermore, not all Infectious receptors will be symptomatic. As has been seen with COVID-19, asymptomatic hosts can contribute to the spread of disease, but go largely undetected and can therefore undermine efforts to control transmission (Gandhi et al. 2020). Although the ability to distinguish the occurrence of symptoms from an Infectious status has proved invaluable in the management of disease, such a classification of ecosystems remains in its infancy with respect to biological invasions. Non-native species may occur in an ecosystem without having a significant impact on native biodiversity or ecosystem function, yet that ecosystem may still contribute to the spread of the species. An "asymptomatic" Infectious state may also occur where non-native species possess covert resting stages (e.g. seeds, rhizomes, spores, cysts and eggs) that remain viable in the receptor without developing into adults, but may be dispersed passively by the transport of soil between ecosystems.

\section{Recovery and resistance}

In microparasitic diseases, the Infectious state comes to an end through the recovery or death of the host. Recovery may result from a natural acquired immune response and may render a receptor Resistant to further infection, either permanently (e.g. measles) or temporarily, in which the receptor becomes Susceptible at some time in the future (e.g. common cold). Alternatively, human intervention such as chemotherapy (e.g. antiviral drugs, antibiotics, fungicides, pesticides etc.) can lead to recovery, but only to the Susceptible rather than Resistant state. Evidence for natural recovery of ecosystems following invasion is scarce, although several cases of boom and bust dynamics of non-native species, where formerly widespread populations collapse, have been documented (Strayer et al. 2017). However, there is no general equivalent of acquired immunity to non-native species. While there is evidence that native insects and pathogens may adapt to non-native plant hosts and may even inflict severe damage, there is limited evidence that these natural enemies impede invasions 
or result in ecosystems no longer being Susceptible (Crous et al. 2017). In most cases, ecosystem recovery is the result of human intervention. Evidence of interventions resulting in successful recovery from biological invasions is mixed with about half of all non-native arthropod eradications being successful, while for non-native plant species most programmes have failed to deliver eradication (Hulme 2020) or promote ecosystem recovery (Prior et al. 2018) due to re-invasion. Nevertheless, possibly with the exception of a few classical biological control programmes, there are no studies suggesting that, even where eradication is completely successful, the ecosystems concerned are subsequently more resistant to future invasion. Therefore, it is likely that, for non-native species invasions, the rates at which Susceptible $(\mu)$ or Infectious $(\gamma)$ receptors become Resistant will be negligible (Fig. 2).

In the case of microparasites, a high rate of transition to the Resistant state shortens the duration of the Infectious state, thus lowering the opportunities for transmission (Diekmann et al. 2013). To ensure the spread of disease under such circumstances, agents require a high transmission rate and short latent period. This points to a major difference from biological invasions in that, without a significant scope for ecosystem recovery, non-native species can persist even in the face of low transmission rates and long lag-phases. An understanding of the role of the Resistant state in the dynamics of disease is essential to the design of effective immunisation programmes. Therefore, more effort should be invested in research on ecosystem resistance to invasion and the development of tools that could be used to increase the resistance of ecosystems following the eradication on a non-native species.

\section{Vital rates}

The incorporation of host vital rates (births and deaths) into microparasite models can have dramatic implications for disease dynamics (Gallos and Fefferman 2015), but it is difficult to conceive of birth and death processes for entire ecosystems. Non-native species can dramatically impact species diversity and ecosystem functions following invasion and they may even transform ecosystems from one state to another (e.g. non-native rabbits impeding woody succession), but the spatial unit itself does not usually disappear (Vilà and Hulme 2017). Even if it is transformed to another ecosystem state (Cobb et al. 2017; Jarnevich et al. 2019; Perry et al. 2015; Stein et al. 2016), the receptor may remain Susceptible to further colonisation by non-native species and it may even continue to be Infectious. Human activities can, of course, create and destroy entire ecosystems. For example, the establishment of new forest plantations or their harvest can influence the spread and persistence of phytophagous non-native arthropods (Be et al. 2017); and newly-created reservoirs (Smith et al. 2015) or coastal marinas (Floerl et al. 2009) may act as stepping stones for the spread of non-native aquatic species. The potential importance of the addition or removal of ecosystems from a landscape for the spread of non-native species has received relatively little attention. but it may be a powerful driver of biological invasions, as well as a useful tool for management (Alharbi and Petrovskii 2019). 


\section{The value of the Epidemiological Framework for Biological Invasions}

The foregoing sections have shown that, just as hosts may be viewed as ecosystems (Rynkiewicz et al. 2015), ecosystems can be viewed as hosts. One of the aims of the Epidemiological Framework for Biological Invasions is that it is designed to transfer the insights from compartment models of microparasitic diseases to the management of non-native species. The potential of this framework can be illustrated using three examples: (i) basic reproductive ratio for invasions; (ii) super-spreaders vs. sinks; and (iii) ring eradication and herd immunity.

\section{Towards a basic reproductive ratio $\boldsymbol{R}_{\boldsymbol{0}}$ for biological invasions}

The Epidemiological Framework for Biological Invasions is receptor-focused and, although complementary to more traditional agent-focused demographic models, it provides new opportunities to understand biological invasions. The agent-centred approach to biological invasions assumes the probability of successful invasion is a function of the intrinsic rate of population increase when a non-native species is rare (Grainger et al. 2019). However, the receptor-centred approach suggests that an estimate of the mean number of Susceptible receptors likely to be colonised from the first Infectious receptor may be a better indicator of invasion risk, since it explicitly includes both population growth and spread. This parameter is equivalent to the basic reproductive ratio $\left(R_{0}\right)$ which is defined as the expected number of secondary infections in a population of Susceptible receptors arising from a single individual during their entire infectious period and it often serves as a threshold parameter that predicts whether an infection will spread. The basic reproductive ratio $\left(R_{0}\right)$ is the product of the transmission rate and the average amount of time a receptor spends in the Infectious state and, the larger its value, the harder it will be to eradicate the microparasite or non-native species (Blackwood and Childs 2018). For non-native species, the duration of the Infectious state can be many decades so even if transmission rates are low, $R_{0}$ will be much greater than 1.0 and the invasion will persist. Therefore, the rate at which a non-native species is eradicated from ecosystems must be higher than the rate at which new ecosystems are colonised. If, as is likely, there are often few options for creating Resistant ecosystems and once a non-native species has been eradicated from an Infectious ecosystem, it reverts to being Susceptible, then the proportion of ecosystems from which invasion must be prevented will be close to 1.0 (Fine et al. 2011). This undoubtedly explains why, once a non-native species is widely established, it becomes almost impossible to eradicate. Perhaps the primary application of $R_{0}$ is not in predicting the difficulty of eradicating an established non-native species, but in assessing the potential risk posed by species that have yet to be introduced. Under this scenario, rather than derive an arbitrary score or probability on invasion likelihood, risk assessment tools could be designed to estimate $R_{0}$. 


\section{Identifying sources, super-spreaders and sinks}

In models of biological invasions, Infectious receptors act as sources that are capable of infecting Susceptible receptors, but can also maintain non-native species populations in Exposed receptors that would otherwise become extinct without immigration. Sink ecosystems have been observed for non-native fish (Dauphinais et al. 2018) and plants (Seipel et al. 2016) while microparasites in dead-end hosts are unable to achieve further transmission (Geoghegan et al. 2016). Similarly, measles in small rural villages is often sustained by the influx of infectious individuals from neighbouring major urban centres (Grenfell and Bolker 1998). In many disease systems, < 20\% of Infectious receptors may be involved in $80 \%$ of transmission (Stein 2011). The receptors that make up this $20 \%$ are usually referred to as super-spreaders and their identification and subsequent targeting is a fundamental goal in disease management. It is unclear if the same 80/20 rule holds for non-native species, but identifying Infectious receptors that are super-spreaders could be an important component of the management of biological invasions. How can managers identify these super-spreaders? Managers surveying the distribution of non-native species may face difficulties in distinguishing between the stochastic population dynamics that may occur during the latent/lag phase in source receptors and the transient dynamics of agents in sink receptors where populations are maintained by immigration. The former scenario requires greater vigilance from managers to ensure the Exposed state does not progress to become Infectious (Fig. $2 \sigma$ ). In contrast, sink receptors play little further part in invasion dynamics, but may divert management resources away from more important targets. The stochastic population dynamics that occur during the lag-phase following infection makes it difficult for managers to distinguish sources from sinks. However, Runge et al. (2006) provide some useful guidance on how this may be done. Transient populations of non-native species are frequently recorded (e.g. as casual alien plants), but the dynamics of these populations are rarely documented (Iles et al. 2016; Brock and Daehler 2020). Distinguishing between sources and sinks is an essential component in managing diseases and biological invasions (Hulme 2020). Unfortunately, data relating to biological invasions tend to score ecosystems as invaded (i.e. Exposed or Infectious) or uninvaded (i.e. Susceptible or Resistant), but rarely quantify the distribution of agents amongst receptors or address the equivalent of the infectivity of a receptor. This issue could be addressed if epidemiological states and transitions were incorporated into spatiotemporal models representing the spread of non-native species through heterogeneous landscapes (Catterall et al. 2012; Mang et al. 2018).

\section{Ring eradication and herd immunity}

A much-debated approach for the management of microparasitic diseases is "ring vaccination" that targets immunisation to particular groups of Infectious receptors in order to prevent the spread of disease agents (Deen and von Seidlein 2018; Merler et 
al. 2016). A similar approach, which might be called "ring eradication" has been put forward for biological invasions, whereby non-native species eradication programmes may initially target small, isolated "satellites" first, rather than a single large core population, since many satellites will contribute disproportionally more to population expansion in a homogeneous environment (Hulme 2006; Kovacs et al. 2011; Panetta and Cacho 2014). However, in contrast to the management of diseases, quantitative assessments of the likelihood of containment of invasion through the targeted control of satellite populations through ring eradication have yet to be undertaken.

A more dramatic form of intervention is the establishment of a cordon sanitaire where locations containing high risk hosts are almost sealed from the outside world with severe restrictions placed on the movement in or out of the cordon sanitaire (Gostin et al. 2020). A dramatic example, recognised as the largest quarantine in history, was the cordon sanitaire imposed on Wuhan, a city of 11 million residents, with closure of all transport in and out of the city for 76 days to limit the spread of COVID-19 (Wan et al. 2020). Similar approaches have been used to prevent the spread of nonnative species, including the establishment of movement controls, such as the Fruit Fly Exclusion Zone in Australia (Dominiak and Mapson 2017) and buffer zones around protected areas to prevent the spread of non-native weeds (Foxcroft et al. 2011).

The concept of "herd immunity" in which there may be a critical community size, beneath which persistence of metapopulations is not possible, has been influential in microparasitic disease management, since it suggests that only a proportion (albeit often high) of receptors needs to be managed (immunised) to prevent the persistence of disease (Metcalf et al. 2015). If applicable to non-native species, the concept of herd immunity could significantly assist control efforts. If a non-native species exhibited a metapopulation structure and was confined to a specific ecosystem type that was patchily distributed (e.g. lake ecosystems), then population persistence would depend on local dynamics and connectivity (Hastings 2014). In theory, reducing local population growth and eradicating the non-native species from a progressively greater proportion of patches to reduce connectivity could lead to the collapse of the metapopulation. Unfortunately, such an approach, while fine in theory, appears difficult to achieve in practice (Garcia-Diaz et al. 2019). Given that for many biological invasions, $\mathrm{R}_{0}$ is much greater than 1.0 , herd immunity would require most ecosystems to be or become Resistant which is unlikely since there is limited knowledge on what makes an ecosystem Resistant. Taken together this suggests that, for most biological invasions, it is currently impractical to attempt the equivalent of herd immunity for ecosystems.

\section{Applying the Epidemiological Framework to Invasions in Lakes}

There appear to be opportunities to apply a more epidemiological perspective to the spatio-temporal dynamics of non-native species, but the real test of the value of the Epidemiological Framework for Biological Invasions will be in its application to a specific case study. Lake ecosystems (including ponds and impoundments) are widely recognised as being discrete units in the landscape and, while connectivity amongst lakes can often 


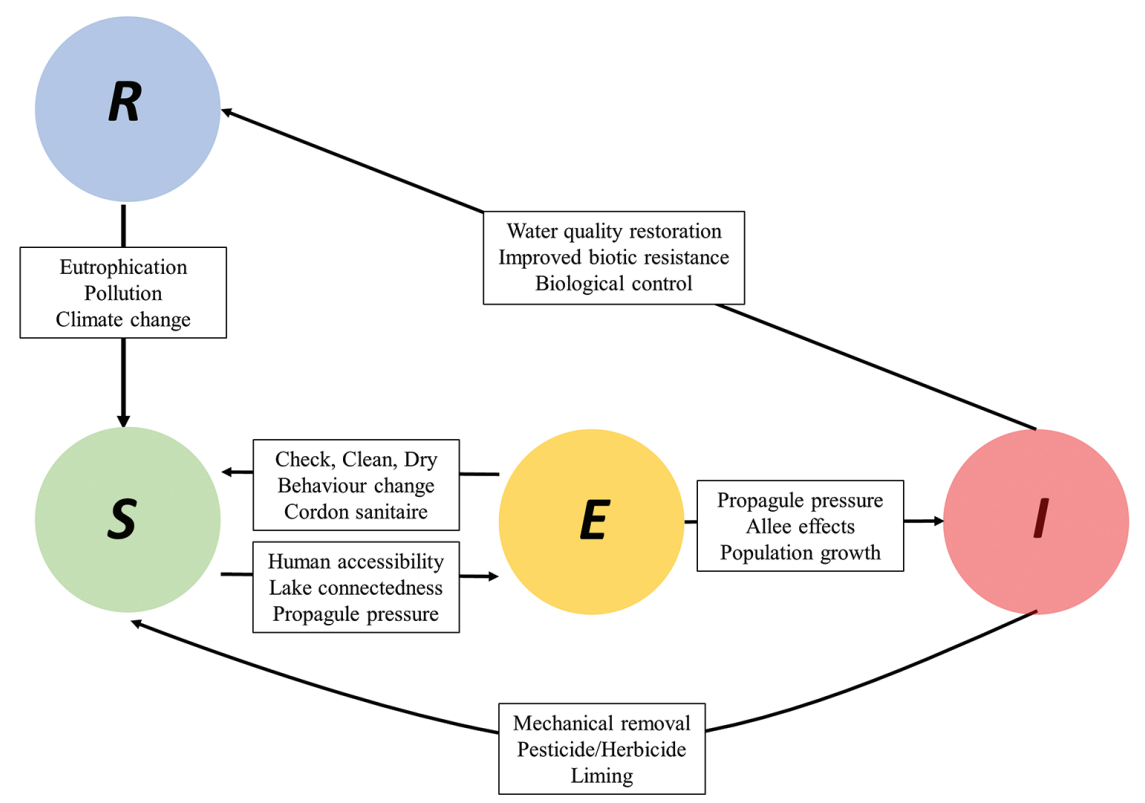

Figure 3. Schematic diagram based on a disease compartment model applied to invasions of lake ecosystems (lakes, ponds and impoundments) to illustrate the different variables that could influence the flows between Resistant, Susceptible, Exposed and Infectious compartments.

occur through natural watercourses or anthropogenic canals, the boundaries between lake ecosystems and surrounding ecosystems are often clear cut (Likens 2010). This discrete nature, combined with the fact that they represent one of the ecosystems most vulnerable to invasion by plants, invertebrates and vertebrates (Carpenter et al. 2011), make lake ecosystems particularly suitable for exploring the value of the Epidemiological Framework for Biological Invasions (Fig. 3). Despite their inherent vulnerability to biological invasions, the extent to which different lake ecosystems are Susceptible to nonnative species colonisation can differ quite markedly even within the same landscape (June-Wells et al. 2013). Water chemistry, in particular the specific conductance and $\mathrm{pH}$, is an important determinant of whether a particular non-native species can establish in a lake ecosystem and can be a significant barrier to invasion, effectively rendering the ecosystem Resistant (Karatayev et al. 2015). Coldwater temperatures may also act as a filter that prevents warmwater-adapted species from establishing self-sustaining populations in lake ecosystems (Rahel and Olden 2008). Thus, for a particular non-native species threat, it may be possible to distinguish Susceptible and Resistant lake ecosystems a priori and so establish the starting conditions for an epidemiological approach to understanding future invasions. Resistant lake ecosystems can become Susceptible when runoff from urban or agricultural land or pollution from domestic or industrial sources alters water conductivity and $\mathrm{pH}$. Similarly, a warming climate may reduce the cold temperature limits that prevent some non-native taxa establishing in a lake ecosystem. However, even when Susceptible, invasion will not occur unless lake ecosystems enter the Exposed class and the likelihood of exposure to non-native species has been 
successfully modelled using environmental parameters that point to metrics capturing accessibility to the human population and connectivity to other lake ecosystems as being critically important (Compton et al. 2012; Leathwick et al. 2016; Tamayo and Olden 2014). The progression of lake ecosystems from the Exposed to the Infectious class will be a function of the propagule pressure (the number and frequency of introductions into a lake ecosystem) and specific attributes of the non-native species of concern, particularly Allee effects and the population growth rate (Gertzen et al. 2011; Leung et al. 2004). For lake ecosystems in the Infectious class, two routes exist for interventions that either result in a shift to the Susceptible or Resistant class. In the former, mechanical or chemical removal of the target non-native species can be successful (Rytwinski et al. 2019), but lake ecosystems often simply return to the Susceptible class and, depending on the unintended side effects of these treatments (e.g. disturbance, mortality of non-target native species), can become more prone to invasion. If lake ecosystems were initially Resistant, but have been converted to Susceptible as a consequence of environmental degradation and then subsequently become Infectious, then the potential exists for reversing the process through restoration of water quality or improving biotic resistance amongst resident species, particularly predators that might feed on non-native species. These interventions could, of course, be implemented before a lake ecosystem enters the Exposed class. Although classical biological controls do not usually remove the target non-native species completely, they have been used successfully to reduce the abundance of specific aquatic weeds and prevent their subsequent re-invasion over several years (Martin et al. 2018). Interventions can also be effective in limiting the transition from Susceptible to Exposed and include deterring or preventing boaters from accessing Susceptible lake ecosystems (e.g. by using a cordon sanitaire), targeted education including the prevention of inadvertent introductions through Check, Clean and Dry campaigns, as well as large-scale education efforts directed towards users of lake ecosystems (Morandi et al. 2015). Intriguingly, there is evidence that lake invertebrates (Freeland et al. 2000), fish (Murphy et al. 2012; Wilberg et al. 2008), waterfowl (Regehr 2011) and aquatic plants (Purves and Dushoff 2005) may exist as metapopulations and, in some cases, exhibit source-sink dynamics. If such a population structure is found for a non-native species, then there may be scope for coordinated interventions at the landscape scale. Of course, identifying the key variables underlying the transitions between different classes in compartment models is only the first step in parameterising an epidemiological model of lake-ecosystem invasions. As yet, the data required to undertake such parameterisation is not available for any non-native species invading lake-ecosystem networks, but the potential for applying the Epidemiological Framework for Biological Invasions appears promising.

\section{Conclusions}

The wide range of insights, tools and approaches, arising from over a century of work in modelling disease dynamics (Rock et al. 2014) has great relevance to the understanding of biological invasions. The basic epidemiological compartment model can be adapt- 
ed to incorporate increasing levels of complexity and realism (Diekmann et al. 2013) and the concepts at its core can, in most cases, be generally applied to the spread and management of non-native species. While models may be translated from diseases to biological invasions with relative ease, the greatest insights will come if they are used to provide information for the monitoring, mapping and management of non-native species. Initial attempts to use statistical techniques, developed in epidemiology to estimate dispersal and receptor properties from spatio-temporal data on biological invasions, are promising (Catterall et al. 2012; Mang et al. 2018). Such an interdisciplinary approach should allow the field of biological invasion modelling to provide the same benefits that epidemiological compartment models have brought to the management of disease.

\section{Acknowledgements}

This work resulted from a workshop (Towards an integrated assessment of the environmental risks posed by non-native species, GMOs and wildlife diseases) held as part of the UK Population Biology Network (UKPopNet) and funded by the Natural Environment Research Council (Agreement R8-H12-01) and English Nature. Its development was stimulated by the workshop on 'Frameworks used in Invasion Science' hosted by the DSI-NRF Centre of Excellence for Invasion Biology that was supported by the National Research Foundation of South Africa and Stellenbosch University. The authors would like to thank John Wilson, Paul Caplat, Gordon Copp and Ernest Gould for comments on a previous version of this manuscript.

\section{References}

Affre L, Suehs CM, Charpentier S, Vilà M, Brundu G, Lambdon P, Traveset A, Hulme PE (2010) Consistency in the habitat degree of invasion for three invasive plant species across Mediterranean islands. Biological Invasions 12: 2537-2548. https://doi.org/10.1007/ s10530-009-9662-6

Aikio S, Duncan RP, Hulme PE (2010) Lag-phases in alien plant invasions: separating the facts from the artefacts. Oikos 119: 370-378. https://doi.org/10.1111/j.16000706.2009.17963.x

Aikio S, Duncan RP, Hulme PE (2012) The vulnerability of habitats to plant invasion: disentangling the roles of propagule pressure, time and sampling effort. Global Ecology and Biogeography 21: 778-786. https://doi.org/10.1111/j.1466-8238.2011.00711.x

Alharbi W, Petrovskii S (2019) Effect of complex landscape geometry on the invasive species spread: Invasion with stepping stones. Journal of Theoretical Biology 464: 85-97. https:// doi.org/10.1016/j.jtbi.2018.12.019

Arora R, Petrov GI, Yakovlev VV, Scully MO (2012) Detecting anthrax in the mail by coherent Raman microspectroscopy. Proceedings of the National Academy of Sciences of the United States of America 109: 1151-1153. https://doi.org/10.1073/pnas.1115242108 
Baker RHA, Black R, Copp GH, Haysom KA, Hulme PE, Thomas MB, Brown A, Brown M, Cannon RJC, Ellis J, Ellis E, Ferris R, Glaves P, Gozlan RE, Holt H, Howe L, Knight JD, MacLeod A, Moore NP, Mumford JD, Murphy ST, Parrott D, Sansford CE, Smith GC, St-Hilaire S, Ward NL (2008) The UK risk assessment scheme for all non-native species. Neobiota 7: 46-57.

Be M, Chase KD, Brockerhoff EG (2017) Use of shelterbelt pine trees as "stepping stones' by Hylastes ater in agricultural landscapes. New Zealand Entomologist 40: 86-91. https://doi. org/10.1080/00779962.2017.1364152

Bestelmeyer BT, Ash A, Brown JR, Densambuu B, Fernández-Giménez M, Johanson J, Levi M, Lopez D, Peinetti R, Rumpff L, Shaver P (2017) State and transition models: theory, applications, and challenges. In: Briske DD (Ed.) Rangeland Systems: Processes, Management and Challenges. Springer International Publishing, Cham, 303-345. https://doi. org/10.1007/978-3-319-46709-2_9

Beyrer C, Baral SD, van Griensven F, Goodreau SM, Chariyalertsak S, Wirtz AL, Brookmeyer R (2012) Global epidemiology of HIV infection in men who have sex with men. Lancet 380: 367-377. https://doi.org/10.1016/S0140-6736(12)60821-6

Blackwood JC, Childs LM (2018) An introduction to compartmental modeling for the budding infectious disease modeler. Letters in Biomathematics 5: 195-221. https://doi. org/10.30707/LiB5.1Blackwood

Brauer F, Castillo-Chavez C (2010) Mathematical models in population biology and epidemiology. Springer, Dordrecht. https://doi.org/10.1007/978-1-4614-1686-9_9

Briscoe NJ, Elith J, Salguero-Gomez R, Lahoz-Monfort JJ, Camac JS, Giljohann KM, Holden MH, Hradsky BA, Kearney MR, McMahon SM, Phillips BL, Regan TJ, Rhodes JR, Vesk PA, Wintle BA, Yen JDL, Guillera-Arroita G (2019) Forecasting species range dynamics with process-explicit models: matching methods to applications. Ecology Letters 22: 1940-1956. https://doi.org/10.1111/ele.13348

Brock KC, Daehler CC (2020) Applying an invasion and risk framework to track non-native island floras: a case study of challenges and solutions in Hawai'i. In: Wilson JR, Bacher S, Daehler CC, Groom QJ, Kumschick S, Lockwood JL, Robinson TB, Zengeya TA, Richardson DM (Eds) Frameworks used in Invasion Science. NeoBiota 62: 55-79. https://doi. org/10.3897/neobiota.62.52764

Bufford JL, Hulme PE, Sikes BA, Cooper JA, Johnston PR, Duncan RP (2016) Taxonomic similarity, more than contact opportunity, explains novel plant-pathogen associations between native and alien taxa. New Phytologist 212: 657-667. https://doi.org/10.1111/nph.14077

Carpenter SR, Stanley EH, Vander Zanden MJ (2011) State of the world's freshwater ecosystems: Physical, chemical, and biological changes. Annual Review of Environment and Resources 36: 75-99. https://doi.org/10.1146/annurev-environ-021810-094524

Casadevall A, Pirofski L-A (2018) What is a host? Attributes of individual susceptibility. Infection and Immunity 86: e00636-00617. https://doi.org/10.1128/IAI.00636-17

Cassey P, Prowse TAA, Blackburn TM (2014) A population model for predicting the successful establishment of introduced bird species. Oecologia 175: 417-428. https://doi. org/10.1007/s00442-014-2902-1 
Catterall S, Cook AR, Marion G, Butler A, Hulme PE (2012) Accounting for uncertainty in colonisation times: a novel approach to modelling the spatio-temporal dynamics of alien invasions using distribution data. Ecography 35: 901-911. https://doi.org/10.1111/ j.1600-0587.2011.07190.x

Charu V, Zeger S, Gog J, Bjornstad ON, Kissler S, Simonsen L, Grenfell BT, Viboud C (2017) Human mobility and the spatial transmission of influenza in the United States. PLoS Computational Biology 13: e1005382. https://doi.org/10.1371/journal.pcbi.1005382

Chisholm RH, Campbell PT, Wu Y, Tong SYC, McVernon J, Geard N (2018) Implications of asymptomatic carriers for infectious disease transmission and control. Royal Society Open Science 5: 172341. https://doi.org/10.1098/rsos.172341

Chytrý M, Jarošík V, Pyšek P, Hájek O, Knollová I, Tichý L, Danihelka J (2008) Separating habitat invasibility by alien plants from the actual level of invasion. Ecology 89: 15411553. https://doi.org/10.1890/07-0682.1

Claflin SB, Jones LE, Thaler JS, Power AG (2017) Crop-dominated landscapes have higher vector-borne plant virus prevalence. Journal of Applied Ecology 54: 1190-1198. https:// doi.org/10.1111/1365-2664.12831

Cobb RC, Ruthrof KX, Breshears DD, Lloret F, Aakala T, Adams HD, Anderegg WRL, Ewers BE, Galiano L, Grunzweig JM, Hartmann H, Huang CY, Klein T, Kunert N, Kitzberger T, Landhausser SM, Levick S, Preisler Y, Suarez ML, Trotsiuk V, Zeppel MJB (2017) Ecosystem dynamics and management after forest die-off: a global synthesis with conceptual state-and-transition models. Ecosphere 8: e02034. https://doi.org/10.1002/ecs2.2034

Collinge J, Whitfield J, McKintosh E, Beck J, Mead S, Thomas DJ, Alpers MP (2006) Kuru in the $21^{\text {st }}$ century - an acquired human prion disease with very long incubation periods. Lancet 367: 2068-2074. https://doi.org/10.1016/S0140-6736(06)68930-7

Compton TJ, De Winton M, Leathwick JR, Wadhwa S (2012) Predicting spread of invasive macrophytes in New Zealand lakes using indirect measures of human accessibility. Freshwater Biology 57: 938-948. https://doi.org/10.1111/j.1365-2427.2012.02754.x

Coutts SR, Helmstedt KJ, Bennett JR (2018) Invasion lags: The stories we tell ourselves and our inability to infer process from pattern. Diversity and Distributions 24: 244-251. https://doi.org/10.1111/ddi.12669

Crous CJ, Burgess TI, Le Roux JJ, Richardson DM, Slippers B, Wingfield MJ (2017) Ecological disequilibrium drives insect pest and pathogen accumulation in non-native trees. AoB Plants 9: plw081. https://doi.org/10.1093/aobpla/plw081

Crowl TA, Crist TO, Parmenter RR, Belovsky G, Lugo AE (2008) The spread of invasive species and infectious disease as drivers of ecosystem change. Frontiers in Ecology and the Environment 6: 238-246. https://doi.org/10.1890/070151

Cunniffe NJ, Cobb RC, Meentemeyer RK, Rizzo DM, Gilligan CA (2016) Modeling when, where, and how to manage a forest epidemic, motivated by sudden oak death in California. Proceedings of the National Academy of Sciences 113: 5640-5645. https://doi. org/10.1073/pnas.1602153113

Dauphinais JD, Miller LM, Swanson RG, Sorensen PW (2018) Source-sink dynamics explain the distribution and persistence of an invasive population of common carp across a model 
Midwestern watershed. Biological Invasions 20: 1961-1976. https://doi.org/10.1007/ s10530-018-1670-y

Dawson W, Burslem D, Hulme PE (2011) The comparative importance of species traits and introduction characteristics in tropical plant invasions. Diversity and Distributions 17: 1111-1121. https://doi.org/10.1111/j.1472-4642.2011.00796.x

de la Fuente B, Saura S, Beck PSA (2018) Predicting the spread of an invasive tree pest: The pine wood nematode in Southern Europe. Journal of Applied Ecology 55: 2374-2385. https://doi.org/10.1111/1365-2664.13177

Deen J, von Seidlein L (2018) The case for ring vaccinations with special consideration of oral cholera vaccines. 14: 2069-2074. https://doi.org/10.1080/21645515.2018.1462068

Del Valle SY, Hyman JM, Chitnis N (2013) Mathematical models of contact patterns between age groups for predicting the spread of infectious diseases. Mathematical Biosciences and Engineering 10: 1475-1497. https://doi.org/10.3934/mbe.2013.10.1475

Diekmann O, Heesterbeek H, Britton T (2013) Mathematical tools for understanding infectious disease dynamics. Princeton University Press, Princeton. https://doi.org/10.1515/9781400845620

Dominiak BC, Mapson R (2017) Revised distribution of Bactrocera tryoni in eastern Australia and effect on possible incursions of Mediterranean fruit fly: Development of Australia's eastern trading block. Journal of Economic Entomology 110: 2459-2465. https://doi. org/10.1093/jee/tox237

Doran KS, Fulde M, Gratz N, Kim BJ, Nau R, Prasadarao N, Schubert-Unkmeir A, Tuomanen EI, Valentin-Weigand P (2016) Host-pathogen interactions in bacterial meningitis. Acta Neuropathologica 131: 185-209. https://doi.org/10.1007/s00401-015-1531-z

Downing JA, Prairie YT, Cole JJ, Duarte CM, Tranvik LJ, Striegl RG, McDowell WH, Kortelainen P, Caraco NF, Melack JM, Middelburg JJ (2006) The global abundance and size distribution of lakes, ponds, and impoundments. Limnology and Oceanography 51 : 2388-2397. https://doi.org/10.4319/lo.2006.51.5.2388

Drake DAR, Mandrak NE (2014) Bycatch, bait, anglers, and roads: quantifying vector activity and propagule introduction risk across lake ecosystems. Ecological Applications 24: 877-894. https://doi.org/10.1890/13-0541.1

Drake JM (2005) Risk analysis for invasive species and emerging infectious diseases: Concepts and applications. American Midland Naturalist 153: 4-19. https://doi.org/10.1674/00030031(2005)153[0004:RAFISA]2.0.CO;2

Drake JM, Lodge DM (2006) Allee effects, propagule pressure and the probability of establishment: risk analysis for biological invasions. Biological Invasions 8: 365-375. https://doi. org/10.1007/s10530-004-8122-6

Early R, Bradley BA, Dukes JS, Lawler JJ, Olden JD, Blumenthal DM, Gonzalez P, Grosholz ED, Ibanez I, Miller LP, Sorte CJB, Tatem AJ (2016) Global threats from invasive alien species in the twenty-first century and national response capacities. Nature Communications 7: 12485. https://doi.org/10.1038/ncomms12485

Engering A, Hogerwerf L, Slingenbergh J (2013) Pathogen-host-environment interplay and disease emergence. Emerging Microbes \& Infections 2: 1-7. https://doi.org/10.1038/emi.2013.5

Enright J, Kao RR (2018) Epidemics on dynamic networks. Epidemics 24: 88-97. https://doi. org/10.1016/j.epidem.2018.04.003 
Evans P, Brown CD (2017) The boreal-temperate forest ecotone response to climate change. Environmental Reviews 25: 423-431. https://doi.org/10.1139/er-2017-0009

Fang FC, Frawley ER, Tapscott T, Vazquez-Torres A (2016) Bacterial stress responses during host infection. Cell Host \& Microbe 20: 133-143. https://doi.org/10.1016/j.chom.2016.07.009

Fellous S, Duncan AB, Quillery E, Vale PF, Kaltz O (2012) Genetic influence on disease spread following arrival of infected carriers. Ecology Letters 15: 186-192. https://doi. org/10.1111/j.1461-0248.2011.01723.x

Fine P, Eames K, Heymann DL (2011) "Herd immunity": A rough guide. Clinical Infectious Diseases 52: 911-916. https://doi.org/10.1093/cid/cir007

Floerl O, Inglis GJ, Dey K, Smith A (2009) The importance of transport hubs in stepping-stone invasions. Journal of Applied Ecology 46:37-45. https://doi.org/10.1111/j.1365-2664.2008.01540.x

Foxcroft LC, Jarošík V, Pyšek P, Richardson DM, Rouget M (2011) Protected area boundaries as filters of plant invasions. Conservation Biology 25: 400-405. https://doi.org/10.1111/ j.1523-1739.2010.01617.x

Freeland JR, Noble LR, Okamura B (2000) Genetic consequences of the metapopulation biology of a facultatively sexual freshwater invertebrate. Journal of Evolutionary Biology 13: 383-395. https://doi.org/10.1046/j.1420-9101.2000.00192.x

Gallos LK, Fefferman NH (2015) The effect of disease-induced mortality on structural network properties. PLoS One 10: e0136704. https://doi.org/10.1371/journal.pone.0136704

Gandhi M, Yokoe DS, Havlir DV (2020) Asymptomatic transmission, the Achilles' heel of current strategies to control COVID-19. New England Journal of Medicine 382: 2158-2160. https://doi.org/10.1056/NEJMe2009758

Garcia-Diaz P, Anderson DP, Lurgi M (2019) Evaluating the effects of landscape structure on the recovery of an invasive vertebrate after population control. Landscape Ecology 34: 615-626. https://doi.org/10.1007/s10980-019-00796-w

Geoghegan JL, Senior AM, Di Giallonardo F, Holmes EC (2016) Virological factors that increase the transmissibility of emerging human viruses. Proceedings of the National Academy of Sciences of the United States of America 113: 4170-4175. https://doi.org/10.1073/pnas.1521582113

Gertzen EL, Leung B, Yan ND (2011) Propagule pressure, Allee effects and the probability of establishment of an invasive species (Bythotrephes longimanus). Ecosphere 2: art30. https:// doi.org/10.1890/ES10-00170.1

Gignoux J, Davies ID, Flint SR, Zucker JD (2011) The ecosystem in practice: Interest and problems of an old definition for constructing ecological models. Ecosystems 14: 10391054. https://doi.org/10.1007/s10021-011-9466-2

Gilligan CA (2008) Sustainable agriculture and plant diseases: an epidemiological perspective. Philosophical Transactions of the Royal Society B-Biological Sciences 363: 741-759. https://doi.org/10.1098/rstb.2007.2181

Gioria M, Osborne BA (2014) Resource competition in plant invasions: emerging patterns and research needs. Frontiers in Plant Science 5: Article 501. https://doi.org/10.3389/ fpls.2014.00501

Gostin LO, Friedman EA, Wetter SA (2020) Responding to Covid-19: How to navigate a public health emergency legally and ethically. Hastings Center Report 50: 8-12. https:// doi.org/10.1002/hast.1090 
Gottdenker NL, Streicker DG, Faust CL, Carroll CR (2014) Anthropogenic land use change and infectious diseases: A review of the evidence. Ecohealth 11: 619-632. https://doi. org/10.1007/s10393-014-0941-z

Grainger TN, Levine JM, Gilbert B (2019) The invasion criterion: A common currency for ecological research. Trends in Ecology \& Evolution 34: 925-935. https://doi.org/10.1016/j. tree.2019.05.007

Grenfell B, Harwood J (1997) (Meta)population dynamics of infectious diseases. Trends in Ecology \& Evolution 12: 395-399. https://doi.org/10.1016/S0169-5347(97)01174-9

Grenfell BT, Bolker BM (1998) Cities and villages: infection hierarchies in a measles metapopulation. Ecology Letters 1: 63-70. https://doi.org/10.1046/j.1461-0248.1998.00016.x

Guo Q, Fei S, Dukes JS, Oswalt CM, III BVI, Potter KM (2015) A unified approach for quantifying invasibility and degree of invasion. Ecology 96: 2613-2621. https://doi. org/10.1890/14-2172.1

Halliday JEB, Hampson K, Hanley N, Lembo T, Sharp JP, Haydon DT, Cleaveland S (2017) Driving improvements in emerging disease surveillance through locally relevant capacity strengthening. Science 357: 146-148. https://doi.org/10.1126/science.aam8332

Hastings A (2014) Persistence and management of spatially distributed populations. Population Ecology 56: 21-26. https://doi.org/10.1007/s10144-013-0416-z

Hengeveld R (1989) Dynamics of Biological Invasions. Chapman and Hall, London, UK.

Hollingsworth TD, Pulliam JRC, Funk S, Truscott JE, Isham V, Lloyd AL (2015) Seven challenges for modelling indirect transmission: Vector-borne diseases, macroparasites and neglected tropical diseases. Epidemics 10: 16-20. https://doi.org/10.1016/j.epidem.2014.08.007

Hui C, Richardson DM (2017) Invasion Dynamics. Oxford University Press, Oxford. https:// doi.org/10.1093/acprof:oso/9780198745334.001.0001

Hulme PE (2006) Beyond control: wider implications for the management of biological invasions. Journal of Applied Ecology 43: 835-847. https://doi.org/10.1111/j.1365-2664.2006.01227.x

Hulme PE (2014) Invasive species challenge the global response to emerging diseases. Trends in Parasitology 30: 267-270. https://doi.org/10.1016/j.pt.2014.03.005

Hulme PE (2017) Climate change and biological invasions: evidence, expectations, and response options. Biological Reviews 92: 1297-1313. https://doi.org/10.1111/brv.12282

Hulme PE (2020) Plant invasions in New Zealand: global lessons in prevention, eradication and control. Biological Invasions 22: 1539-1562. https://doi.org/10.1007/s10530-02002224-6

Hulme PE, Bacher S, Kenis M, Klotz S, Kühn I, Minchin D, Nentwig W, Olenin S, Panov V, Pergl J, Pyšek P, Roques A, Sol D, Solarz W, Vilà M (2008) Grasping at the routes of biological invasions: a framework for integrating pathways into policy. Journal of Applied Ecology 45: 403-414. https://doi.org/10.1111/j.1365-2664.2007.01442.x

Iles DT, Salguero-Gomez R, Adler PB, Koons DN (2016) Linking transient dynamics and life history to biological invasion success. Journal of Ecology 104: 399-408. https://doi. org/10.1111/1365-2745.12516

Ireland KB, van Klinken R, Cook DC, Logan D, Jamieson L, Tyson JL, Hulme PE, Worner S, Brockerhoff EG, Fletcher JD, Rodoni B, Christopher M, Ludowici VA, Bulman L, Teulon D, Crampton KA, Hodda M, Paini D (2020) Plant Pest Impact Metric System (PPIMS): 
Framework and guidelines for a common set of metrics to classify and prioritise plant pests. Crop Protection 128: 105003. https://doi.org/10.1016/j.cropro.2019.105003

Jarnevich CS, Thomas CC, Young NE, Backer D, Cline S, Frid L, Grissom P (2019) Developing an expert elicited simulation model to evaluate invasive species and fire management alternatives. Ecosphere 10: e02730. https://doi.org/10.1002/ecs2.2730

Jeschke JM, Heger T (2018) Invasion Biology: Hypotheses and Evidence. CABI, Wallingford. https://doi.org/10.1079/9781780647647.0000

Johnson EE, Escobar LE, Zambrana-Torrelio C (2019) An ecological framework for modeling the geography of disease transmission. Trends in Ecology \& Evolution 34: 655-668. https://doi.org/10.1016/j.tree.2019.03.004

Johnson PTJ, Townsend AR, Cleveland CC, Glibert PM, Howarth RW, McKenzie VJ, Rejmankova E, Ward MH (2010) Linking environmental nutrient enrichment and disease emergence in humans and wildlife. Ecological Applications 20: 16-29. https://doi. org/10.1890/08-0633.1

Joos L, Chhajed PN, Wallner J, Battegay M, Steiger J, Gratwohl A, Tamm M (2007) Pulmonary infections diagnosed by BAL: A 12-year experience in 1066 immunocompromised patients. Respiratory Medicine 101: 93-97. https://doi.org/10.1016/j.rmed.2006.04.006

June-Wells M, Gallagher F, Gibbons J, Bugbee G (2013) Water chemistry preferences of five nonnative aquatic macrophyte species in Connecticut: a preliminary risk assessment tool. Lake and Reservoir Management 29: 303-316. https://doi.org/10.1080/10402381.2013.857742

Karatayev AY, Burlakova LE, Mastitsky SE, Padilla DK (2015) Predicting the spread of aquatic invaders: insight from 200 years of invasion by zebra mussels. Ecological Applications 25: 430-440. https://doi.org/10.1890/13-1339.1

Keeling MJ, Woolhouse MEJ, May RM, Davies G, Grenfell BT (2003) Modelling vaccination strategies against foot-and-mouth disease. Nature 421: 136-142. https://doi.org/10.1038/ nature 01343

Kirby RS, Delmelle E, Eberth JM (2017) Advances in spatial epidemiology and geographic information systems. Annals of Epidemiology 27: 1-9. https://doi.org/10.1016/j.annepidem.2016.12.001

Kleczkowski A, Hoyle A, McMenemy P (2019) One model to rule them all? Modelling approaches across OneHealth for human, animal and plant epidemics. Philosophical Transactions of the Royal Society B-Biological Sciences 374: 20180255. https://doi.org/10.1098/ rstb.2018.0255

Kot M, Lewis MA, Neubert MG (2012) Integrodifference equations. In: Hastings A, Gross L (Eds) Encyclopedia of Theoretical Ecology. University of California Press, Berkeley, 381-384.

Kovacs KF, Mercader RJ, Haight RG, Siegert NW, McCullough DG, Liebhold AM (2011) The influence of satellite populations of emerald ash borer on projected economic costs in US communities, 2010-2020. Journal of Environmental Management 92: 2170-2181. https://doi.org/10.1016/j.jenvman.2011.03.043

Liebhold AW, Keitt TH, Goel N, Bertelsmeier C (2020) Scale invariance in the spatial-dynamics of biological invasions. In: Wilson JR, Bacher S, Daehler CC, Groom QJ, Kumschick S, Lockwood JL, Robinson TB, Zengeya TA, Richardson DM (Eds) Frameworks used in Invasion Science. NeoBiota 62: 269-278. https://doi.org/10.3897/neobiota.62.53213 
Leathwick JR, Collier KJ, Hicks BJ, Ling N, Stichbury G, de Winton M (2016) Predictions of establishment risk highlight biosurveillance priorities for invasive fish in New Zealand lakes. Freshwater Biology 61: 1522-1535. https://doi.org/10.1111/fwb.12792

Leung B, Drake JM, Lodge DM (2004) Predicting invasions: Propagule pressure and the gravity of Allee effects. Ecology 85: 1651-1660. https://doi.org/10.1890/02-0571

Lewis MA, Petrovskii SV, Potts JR (2016) The mathematics behind biological invasions. Springer, Cham, Switzerland. https://doi.org/10.1007/978-3-319-32043-4

Li RY, Xu L, Bjornstad ON, Liu KK, Song T, Chen AF, Xu B, Liu QY, Stenseth NC (2019) Climate-driven variation in mosquito density predicts the spatiotemporal dynamics of dengue. Proceedings of the National Academy of Sciences of the United States of America 116: 3624-3629. https://doi.org/10.1073/pnas.1806094116

Liccardo A, Fierro A (2015) Multiple lattice model for influenza spreading. PLoS One 10: e0141065. https://doi.org/10.1371/journal.pone.0141065

Likens GE (2010) Lake Ecosystem Ecology: A Global Perspective. Academic Press, San Diego. Lindström T, Håkansson N, Wennergren U (2011) The shape of the spatial kernel and its implications for biological invasions in patchy environments. Proceedings of the Royal Society B: Biological Sciences 278: 1564-1571. https://doi.org/10.1098/rspb.2010.1902

Loker ES, Hofkin BV (2015) Parasitology: A Conceptual Approach. CRC Press, Boca Raton. https://doi.org/10.1201/9780429258695

Mang T, Essl F, Moser D, Kleinbauer I, Dullinger S (2018) An integrated, spatio-temporal modelling framework for analysing biological invasions. Diversity and Distributions 24: 652-665. https://doi.org/10.1111/ddi.12707

Martin GD, Coetzee JA, Weyl PSR, Parkinson MC, Hill MP (2018) Biological control of Salvinia molesta in South Africa revisited. Biological Control 125: 74-80. https://doi. org/10.1016/j.biocontrol.2018.06.011

Merler S, Ajelli M, Fumanelli L, Parlamento S, Piontti APY, Dean NE, Putoto G, Carraro D, Longini IM, Halloran ME, Vespignani A (2016) Containing ebola at the source with ring vaccination. Plos Neglected Tropical Diseases 10: e0005093. https://doi.org/10.1371/ journal.pntd.0005093

Metcalf CJE, Ferrari M, Graham AL, Grenfell BT (2015) Understanding herd immunity. Trends in Immunology 36: 753-755. https://doi.org/10.1016/j.it.2015.10.004

Morand S, Krasnov BR, Littlewood DTJ (2015) Parasite diversity and diversification: Evolutionary ecology meets phylogenetics. Cambridge University Press, Cambridge. https://doi. org/10.1017/CBO9781139794749

Morandi MJ, Manning NF, Bossenbroek JM, Jerde CL (2015) Assessing the influence of different inland lake management strategies on human-mediated invasive species spread. Management of Biological Invasions 6: 57-69. https://doi.org/10.3391/mbi.2015.6.1.05

Moslonka-Lefebvre M, Finley A, Dorigatti I, Dehnen-Schmutz K, Harwood T, Jeger MJ, Xu XM, Holdenrieder O, Pautasso M (2011) Networks in plant epidemiology: From genes to landscapes, countries, and continents. Phytopathology 101: 392-403. https://doi. org/10.1094/PHYTO-07-10-0192

Murphy S, Collins NC, Doka SE, Fryer BJ (2012) Evidence of yellow perch, largemouth bass and pumpkinseed metapopulations in coastal embayments of Lake Ontario. Environmental Biology of Fishes 95: 213-226. https://doi.org/10.1007/s10641-012-9978-4 
Ogden NH, Wilson JRU, Richardson DM, Hui C, Davies SJ, Kumschick S, Le Roux JJ, Measey J, Saul WC, Pulliam JRC (2019) Emerging infectious diseases and biological invasions: a call for a One Health collaboration in science and management. Royal Society Open Science 6: 181577. https://doi.org/10.1098/rsos.181577

Oh CO, O'Keefe DM, Lee JS, Lee S (2018) Economic values of a public outreach and education program for aquatic invasive species prevention. Human Dimensions of Wildlife 23: 399-416. https://doi.org/10.1080/10871209.2018.1446230

Oliveras I, Malhi Y (2016) Many shades of green: the dynamic tropical forest-savannah transition zones. Philosophical Transactions of the Royal Society B-Biological Sciences 371: 20150308. https://doi.org/10.1098/rstb.2015.0308

Orsel K, Bouma A, Dekker A, Stegeman JA, de Jong MCM (2009) Foot and mouth disease virus transmission during the incubation period of the disease in piglets, lambs, calves, and dairy cows. Preventive Veterinary Medicine 88: 158-163. https://doi.org/10.1016/j. prevetmed.2008.09.001

Paini DR, Sheppard AW, Cook DC, De Barro PJ, Worner SP, Thomas MB (2016) Global threat to agriculture from invasive species. Proceedings of the National Academy of Sciences of the United States of America 113: 7575-7579. https://doi.org/10.1073/pnas.1602205113

Panetta FD, Cacho OJ (2014) Designing weed containment strategies: An approach based on feasibilities of eradication and containment. Diversity and Distributions 20: 555-566. https://doi.org/10.1111/ddi.12170

Parratt SR, Numminen E, Laine AL (2016) Infectious disease dynamics in heterogeneous landscapes. Annual Review of Ecology, Evolution, and Systematics 47: 283-306. https://doi. org/10.1146/annurev-ecolsys-121415-032321

Perry GLW, Wilmshurst JM, Ogden J, Enright NJ (2015) Exotic mammals and invasive plants alter fire-related thresholds in southern temperate forested landscapes. Ecosystems 18: 1290-1305. https://doi.org/10.1007/s10021-015-9898-1

Pichlmueller F, Russell JC (2018) Survivors or reinvaders? Intraspecific priority effect masks reinvasion potential. Biological Conservation 227: 213-218. https://doi.org/10.1016/j. biocon.2018.09.020

Prior KM, Adams DC, Klepzig KD, Hulcr J (2018) When does invasive species removal lead to ecological recovery? Implications for management success. Biological Invasions 20: 267283. https://doi.org/10.1007/s10530-017-1542-x

Purves DW, Dushoff J (2005) Directed seed dispersal and metapopulation response to habitat loss and disturbance: application to Eichhornia paniculata. Journal of Ecology 93: 658669. https://doi.org/10.1111/j.1365-2745.2005.00988.x

Pysek P, Hulme PE (2005) Spatio-temporal dynamics of plant invasions: linking pattern to process. Ecoscience 12: 302-315. https://doi.org/10.2980/i1195-6860-12-3-302.1

Rahel FJ, Olden JD (2008) Assessing the effects of climate change on aquatic invasive species. Conservation Biology 22: 521-533. https://doi.org/10.1111/j.1523-1739.2008.00950.x

Regehr HM (2011) Movement rates and distances of wintering harlequin ducks: implications for population structure. Waterbirds 34: 19-31. https://doi.org/10.1675/063.034.0103

Riitters K, Potter K, Iannone BV, Oswalt C, Fei SL, Guo QF (2018) Landscape correlates of forest plant invasions: a high-resolution analysis across the eastern United States. Diversity and Distributions 24: 274-284. https://doi.org/10.1111/ddi.12680 
Rock K, Brand S, Moir J, Keeling MJ (2014) Dynamics of infectious diseases. Reports on Progress in Physics 77: 026602. https://doi.org/10.1088/0034-4885/77/2/026602

Rossi G, Smith RL, Pongolini S, Bolzoni L (2017) Modelling farm-to-farm disease transmission through personnel movements: from visits to contacts, and back. Scientific Reports 7: 2375. https://doi.org/10.1038/s41598-017-02567-6

Rouget M, Robertson MP, Wilson JRU, Hui C, Essl F, Renteria JL, Richardson DM (2016) Invasion debt - quantifying future biological invasions. Diversity and Distributions 22: 445-456. https://doi.org/10.1111/ddi.12408

Runge JP, Runge MC, Nichols JD (2006) The role of local populations within a landscape context: Defining and classifying sources and sinks. The American Naturalist 167: 925-938. https://doi.org/10.1086/503531

Rynkiewicz EC, Pedersen AB, Fenton A (2015) An ecosystem approach to understanding and managing within-host parasite community dynamics. Trends in Parasitology 31: 212-221. https://doi.org/10.1016/j.pt.2015.02.005

Rytwinski T, Taylor JJ, Donaldson LA, Britton JR, Browne DR, Gresswell RE, Lintermans M, Prior KA, Pellatt MG, Vis C, Cooke SJ (2019) The effectiveness of non-native fish removal techniques in freshwater ecosystems: a systematic review. Environmental Reviews 27: 71-94. https://doi.org/10.1139/er-2018-0049

Samuel MD, Hobbelen PHF, DeCastro F, Ahumada JA, LaPointe DA, Atkinson CT, Woodworth BL, Hart PJ, Duffy DC (2011) The dynamics, transmission, and population impacts of avian malaria in native Hawaiian birds: a modeling approach. Ecological Applications 21: 2960-2973. https://doi.org/10.1890/10-1311.1

Schulz AN, Lucardi RD, Marsico TD (2019) Successful invasions and failed biocontrol: The role of antagonistic species interactions. BioScience 69: 711-724. https://doi.org/10.1093/ biosci/biz075

Seabloom EW, Borer ET, Gross K, Kendig AE, Lacroix C, Mitchell CE, Mordecai EA, Power AG (2015) The community ecology of pathogens: coinfection, coexistence and community composition. Ecology Letters 18: 401-415. https://doi.org/10.1111/ele.12418

Seebens H, Briski E, Ghabooli S, Shiganova T, MacIsaac HJ, Blasius B (2019) Non-native species spread in a complex network: the interaction of global transport and local population dynamics determines invasion success. Proceedings of the Royal Society B-Biological Sciences 286: 20190036. https://doi.org/10.1098/rspb.2019.0036

Seipel T, Alexander JM, Edwards PJ, Kueffer C (2016) Range limits and population dynamics of non-native plants spreading along elevation gradients. Perspectives in Plant Ecology Evolution and Systematics 20: 46-55. https://doi.org/10.1016/j.ppees.2016.04.001

Shigesada N, Kawasaki K (1997) Biological Invasions: Theory and Practice. Oxford University Press, Oxford.

Siebert U, Alagoz O, Bayoumi AM, Jahn B, Owens DK, Cohen DJ, Kuntz KM, Pract I-SMGR (2012) State-transition modeling: A report of the ISPOR-SMDM modeling good research practices task force-3. Value in Health 15: 812-820. https://doi.org/10.1016/j.jval.2012.06.014

Silk MJ, Croft DP, Delahay RJ, Hodgson DJ, Boots M, Weber N, McDonald RA (2017) Using social network measures in wildlife disease ecology, epidemiology, and management. BioScience 67: 245-257. https://doi.org/10.1093/biosci/biw175 
Simberloff D (2006) Invasional meltdown 6 years later: important phenomenon, unfortunate metaphor, or both? Ecology Letters 9: 912-919. https://doi.org/10.1111/j.14610248.2006.00939.x

Simberloff D (2009) The role of propagule pressure in biological invasions. Annual Review of Ecology Evolution and Systematics 40: 81-102. https://doi.org/10.1146/annurev.ecolsys. 110308.120304

Smith BR, Edds DR, Goeckler JM (2015) Lowhead dams and the downstream dispersal of zebra mussels. Hydrobiologia 755: 1-12. https://doi.org/10.1007/s10750-015-2211-7

Smith KF, Dobson AP, McKenzie FE, Real LA, Smith DL, Wilson ML (2005) Ecological theory to enhance infectious disease control and public health policy. Frontiers in Ecology and the Environment 3: 29-37. https://doi.org/10.2307/3868442

Smith V (2007) Host resource supplies influence the dynamics and outcome of infectious disease. Integrative and Comparative Biology 47: 310-316. https://doi.org/10.1093/icb/icm006

Soubeyrand S, de Jerphanion P, Martin O, Saussac M, Manceau C, Hendrikx P, Lannou C (2018) Inferring pathogen dynamics from temporal count data: the emergence of Xylella fastidiosa in France is probably not recent. New Phytologist 219: 824-836. https://doi. org/10.1111/nph.15177

Stein C, Harpole WS, Suding KN (2016) Transitions and invasion along a grazing gradient in experimental California grasslands. Ecology 97: 2319-2330. https://doi.org/10.1002/ecy.1478

Stein RA (2011) Super-spreaders in infectious diseases. International Journal of Infectious Diseases 15: E510-E513. https://doi.org/10.1016/j.ijid.2010.06.020

Strayer DL, D’Antonio CM, Essl F, Fowler MS, Geist J, Hilt S, Jaric I, Johnk K, Jones CG, Lambin X, Latzka AW, Pergl J, Pysek P, Robertson P, von Schmalensee M, Stefansson RA, Wright J, Jeschke JM (2017) Boom-bust dynamics in biological invasions: towards an improved application of the concept. Ecology Letters 20: 1337-1350. https://doi. org/10.1111/ele.12822

Strona G, Carstens CJ, Beck PSA, Han BA (2018) The intrinsic vulnerability of networks to epidemics. Ecological Modelling 383: 91-97. https://doi.org/10.1016/j.ecolmodel.2018.05.013

Sullivan LL, Li B, Miller TEX, Neubert MG, Shaw AK (2017) Density dependence in demography and dispersal generates fluctuating invasion speeds. Proceedings of the National Academy of Sciences 114: 5053-5058. https://doi.org/10.1073/pnas.1618744114

Sun CJ, Hsieh YH, Georgescu P (2018) A model for HIV transmission with two interacting high-risk groups. Nonlinear Analysis-Real World Applications 40: 170-184. https://doi. org/10.1016/j.nonrwa.2017.08.012

Tack AJM, Hakala J, Petaja T, Kulmala M, Laine AL (2014) Genotype and spatial structure shape pathogen dispersal and disease dynamics at small spatial scales. Ecology 95: 703714. https://doi.org/10.1890/13-0518.1

Tadiri CP, Scott ME, Fussmann GF (2018) Microparasite dispersal in metapopulations: a boon or bane to the host population? Proceedings of the Royal Society B-Biological Sciences 285: 20181519. https://doi.org/10.1098/rspb.2018.1519

Takken W, Verhulst NO (2013) Host preferences of blood-feeding mosquitoes. Annual Review of Entomology 58: 433-453. https://doi.org/10.1146/annurev-ento-120811-153618 
Tamayo M, Olden JD (2014) Forecasting the vulnerability of lakes to aquatic plant invasions. Invasive Plant Science and Management 7: 32-45. https://doi.org/10.1614/IPSMD-13-00036.1

Tamburello N, Ma BO, Cote IM (2019) From individual movement behaviour to landscapescale invasion dynamics and management: a case study of lionfish metapopulations. Philosophical Transactions of the Royal Society B-Biological Sciences 374: 20180057. https:// doi.org/10.1098/rstb.2018.0057

Tobin PC, Berec L, Liebhold AM (2011) Exploiting Allee effects for managing biological invasions. Ecology Letters 14: 615-624. https://doi.org/10.1111/j.1461-0248.2011.01614.x

Toruno TY, Stergiopoulos I, Coaker G (2016) Plant-pathogen effectors: Cellular probes interfering with plant defenses in spatial and temporal manners. Annual Review of Phytopathology 54: 419-441. https://doi.org/10.1146/annurev-phyto-080615-100204

Vale PF (2013) Killing them softly: managing pathogen polymorphism and virulence in spatially variable environments. Trends in Parasitology 29: 417-422. https://doi.org/10.1016/j. pt.2013.07.002

Vieira A, Diniz I, Loureiro A, Pereira AP, Silva MC, Varzea V, Batista D (2019) Aggressiveness profiling of the coffee pathogen Colletotrichum kahawae. Plant Pathology 68: 358-368. https://doi.org/10.1111/ppa.12950

Vilà M, Hulme PE (2017) Impact of biological invasions on ecosystem services. Springer, Cham, Switzerland. https://doi.org/10.1007/978-3-319-45121-3

Wan KH, Huang SS, Ko CN, Lam DSC (2020) The end of 'cordon sanitaire' in Wuhan: the role of non-pharmaceutical interventions against COVID-19. Public Health 185: 6-7. https://doi.org/10.1016/j.puhe.2020.05.007

Wang L, Wu JT (2018) Characterizing the dynamics underlying global spread of epidemics. Nature Communications 9: 218. https://doi.org/10.1038/s41467-017-02344-z

White LA, Forester JD, Craft ME (2017) Using contact networks to explore mechanisms of parasite transmission in wildlife. Biological Reviews 92: 389-409. https://doi.org/10.1111/ brv. 12236

Wilberg MJ, Irwin BJ, Jones ML, Bence JR (2008) Effects of source-sink dynamics on harvest policy performance for yellow perch in southern Lake Michigan. Fisheries Research 94: 282-289. https://doi.org/10.1016/j.fishres.2008.05.003

Wilson K, Fenton A, Tompkins A (2019) Wildlife disease ecology: Linking theory to data and application. Cambridge University Press, Cambridge. https://doi. org/10.1017/9781316479964

Wynne NE, Lorenzo MG, Vinauger C (2020) Mechanism and plasticity of vectors' hostseeking behavior. Current Opinion in Insect Science 40: 1-5. https://doi.org/10.1016/j. cois.2020.02.001

Xue L, Jing S, Miller JC, Sun W, Li H, Estrada-Franco JG, Hyman JM, Zhu H (2020) A datadriven network model for the emerging COVID-19 epidemics in Wuhan, Toronto and Italy. Mathematical Biosciences 326:108391. https://doi.org/10.1016/j.mbs.2020.108391 